\title{
Overall Survival and Related Factors of Advanced-stage Epithelial Ovarian Cancer Patients Underwent Debulking Surgery in Jakarta, Indonesia: A Single-center Experience
}

\author{
Hariyono Winarto ${ }^{1 *}\left(\right.$ D), Adithya Welladatika ${ }^{2}$ (D), Muhammad Habiburrahman ${ }^{2}$ (D), Gatot Purwoto ${ }^{1}$, Fitriyadi Kusuma ${ }^{1}$ (D), \\ Tofan Widya Utami ${ }^{1} \mathbb{D}$, Andi Darma Putra ${ }^{1} \mathbb{D}$, Tricia Anggraeni ${ }^{1} \mathbb{D}$, Kartiwa Hadi Nuryanto ${ }^{1} \mathbb{D}$ \\ ${ }^{1}$ Department of Obstetrics and Gynecology, Division of Gynecologic Oncology, Faculty of Medicine, Universitas Indonesia, \\ Dr. Cipto Mangunkusumo Hospital, Jakarta, Indonesia; ${ }^{2}$ Department of Obstetrics and Gynecology, Faculty of Medicine, \\ Universitas Indonesia, Dr. Cipto Mangunkusumo Hospital, Jakarta, Indonesia
}

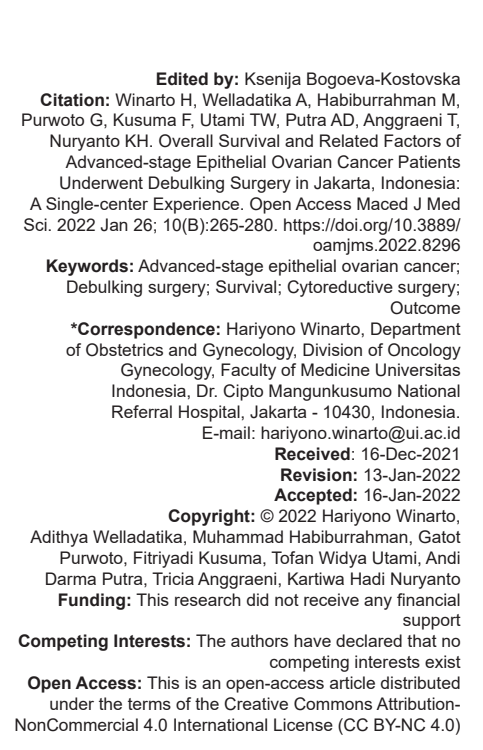

\begin{abstract}
AIM: The worrisome prognosis of advanced-stage epithelial ovarian cancer (EOC) needs a new perspective from developing countries. Thus, we attempted to study the 5-year overall survival (OS) of advanced-stage EOC patients who underwent debulking surgery in an Indonesian tertiary hospital.

METHODS: A retrospective study recruited forty-eight subjects between 2013 and 2015. We conducted multiple logistic regression analyses to predict risk factors leading to unwanted disease outcomes. The OS was evaluated through the Kaplan-Meier curve and Log-rank test. Cox proportional hazards regression examined prognostic factors of patients.

RESULTS: Prominent characteristics of our patients were middle age (mean: $51.9 \pm 8.9$ years), obese, with norma menarche onset, multiparous, not using contraception, premenopausal, with serous EOC, and FIGO stage IIIC. The subjects mainly underwent primary debulking surgery $(66.8 \%)$, with $47.9 \%$ of all individuals acquiring optimal results, $77.1 \%$ of patients treated had the residual disease (RD), and $52.1 \%$ got adjuvant chemotherapy. The risk factor for serous $E O C$ was menopause (odds ratio $[O R]=4.82$ ). The predictors of suboptimal surgery were serous EOC $(O R=8.25)$ and FIGO stage IV $(O R=11.13)$. The different OS and median survival were observed exclusively in $\mathrm{RD}$, making it an independent prognostic factor (hazard ratio $=3.50$ ). 5 -year A five year OS and median survival for patients with advanced-stage EOC who underwent debulking surgery was $37.5 \%$ and 32 months, respectively. Optimal versus suboptimal debulking surgery yielded OS $43.5 \%$ versus $32 \%$ and median survival of 39 versus 29 months. Both optimal and suboptimal debulking surgery followed with chemotherapy demonstrated an OS $40 \%$ lower than those not administered $(46.2 \%$ and $20 \%$, respectively). The highest 5 -year OS was in serous EOC (50\%). Meanwhile, the most extended median survival was with mucinous EOC (45 months).

CONCLUSION: Chemotherapy following optimal and suboptimal debulking surgery has the best OS among approaches researched in this study. RD is a significant prognostic factor among advanced-stage EOC. Suboptimal surgery outcomes can be predicted by stage and histological subtype.
\end{abstract}

\section{Introduction}

Ovarian cancer is the eighth most insidious malignancy among women in 2020 [1], accounting for nearly $4 \%$ of cancers in women worldwide [2]. Approximately $90 \%$ of cases across the world are epithelial ovarian cancer (EOC) [3], with most of the patients $(75 \%)$ diagnosed at an advanced-stage owing to the dearth of adequate screening strategies and vague symptoms [4]. Ovarian cancer has a poor prognosis [5] and is a significant cause of mortality in third place among women with gynecological cancers in 2020 [1]. In Asia/Pacific, the cases of ovarian cancer were 9.2/100,000 [6], and in Indonesia, the incidence and mortality are the thirdhighest, accounting for $7 \%$ of malignancy in women, with $9581 / 14,896$ deaths in 2020 [7]. The latest cancer data in Indonesia is still limited; the incidence was $4.27 / 100,000$ cancer of ovarian cancer between 2005 and 2007 [8].

Based on the stage, more patients are diagnosed with advanced-stage cancer due to the lack of specific symptoms and hidden growth of earlystage EOC, along with lack of proper screening [2], [9]. The 5-year overall survival (OS) rate in EOC patients reaches $49 \%$. Most patients with stage III or IV EOC have a 5 -year OS rate of only $19-47 \%$, while stage I has a 5 -year survival rate of $90 \%$ [9]. The survival rate in EOC patients is highly dependent on the amount of tumor tissue left. The smaller the remaining tissue, the higher the survival rate. Recently, the standard treatment is still cytoreductive surgery to improve the survivability of advanced-stage EOC patients, with either primary or interval debulking surgery following neoadjuvant chemotherapy (NAC-IDS) [9]. The main 
goal of this procedure is to remove as much cancer tissue as possible, including all metastatic tissue.

The tremendous morbidity and mortality of EOC demand a new view from developing countries, where ovarian cancer survival rates are rarely studied. However, Indonesia still lacks comprehensive reports discussing the epidemiological characteristics of this cancer. To the best of the authors' knowledge, no previous study investigated the characteristics, risk factors, prognosis, and survival of EOC in Indonesia. Thus we attempted to characterize the Indonesian patient's clinicopathological, prognostic, and OS aspects of patients with advanced-stage EOC who underwent debulking surgery at a tertiary hospital in Indonesia based on clinical, histopathological, surgical, and chemotherapy parameters.

\section{Materials and Methods}

This study is a retrospective cohort study method in a tertiary healthcare center; Dr. Cipto Mangunkusumo Hospital, Indonesia, from August 2019 until January 2020 using consecutive sampling and including 48 of 53 patients who were diagnosed with advanced-stage EOC who underwent debulking surgery from 2013 until 2015 performed by experienced gynecological oncologists as the sample population. The health research and ethical committee approved the procedures of this research, as laid in the release by the Ethics Committee of Faculty of Medicine, Universitas Indonesia (0614/UN2.F1/ETIK/2018). Patients with comorbidities, pathology reviews showing borderline tumor, and secondary EOC from metastases were excluded in this study. Three patients with comorbidities were excluded because it will be a confounding factor in determining the cause of death, and two patients had metastasis of ovarian cancer from colorectal cancer. The patient was still included in this study sample when there were complications during surgery, such as intestinal perforation or other surrounding organ injuries. The clinicopathological parameters included age, Asia-Pacific standard body mass index (BMI), marital status, the onset of menarche, parity, contraception history, menopausal status, histopathology of EOC, and tumor stage on The International Federation of Gynecology and Obstetrics (FIGO) were analyzed descriptively. Furthermore, we evaluated treatments profiles, including debulking surgery status, debulking surgery type, residual disease (RD) status, its volume, and neoadjuvant and adjuvant chemotherapy status (including numbers of cycles and regimens) compared according to the stage. The definition of RD volume used in this study is $0 \mathrm{~cm}$, microscopic, $<1 \mathrm{~cm}$, and $\geq 1 \mathrm{~cm}$ [10], [11]. We considered debulking optimal if it leaves $<1 \mathrm{~cm}$ of RD. Researchers followed up on the patient's conditions after surgery through medical records and death resumes and directly contacted the patient's or family by phone to acquire the patient's condition 5 years after the operation.

We collected data samples in Microsoft Excel and conducted statistical analyses using SPSS v24.0. Baseline characteristics were presented as descriptive data, and treatment profiles were compared using the Chi-square or Fisher's exact test and Kruskal-Wallis as alternative tests. Then we conducted multiple logistic regression analyses to determine risk factors for seroustype EOC and predictors of suboptimal debulking surgery [12]. We used the Kaplan-Meier curve to generate the 5-year OS analysis according to age, obesity, staging, debulking status, cytoreductive surgery type, $\mathrm{RD}$, adjuvant chemotherapy, a combination of surgery and chemotherapy, histopathology, and serous/nonserous type [13], [14]. The median survival difference between those groups was examined using the MantelCox Log-Rank test [11]. Prognostic factors that meet the proportional hazard $(\mathrm{PH})$ assumption (if the curve lines between groups do not intersect) were included in bivariate Cox regressions to identify significant factors in overall populations. The multivariate analysis will include variables with $p<0.25$ [13]. Data were described as $p$-value, odds ratio (OR), log-rank analysis, hazard ratio $(\mathrm{HR})$, and $95 \%$ confidence interval $(95 \% \mathrm{Cl})$.

\section{Results}

In total, 48 subjects with advanced-stage EOC were recruited during the study in the final analysis, with characteristics illustrated in Table 1. The most common age group was 41-50 years old. According to FIGO, most patients were diagnosed with stage IIIC EOC. Comparing the five subtypes, the three most common histologic subtypes were serous-, clear cell-, and endometrioid carcinoma, but when only comparing the two main subtypes (serous and non-serous EOC), more than half of cases were diagnosed with non-serous EOC. Almost sixty percent of EOC patients were obese. About ninety percent of the patients were married and never used contraception. Half of the subjects were multiparous and were menopausal. All patients had menarche within the age of 12-16 years.

The clinicopathological and therapy profile according to the stage are presented in Table 2. It showed that $>50 \%$ of subjects in either stage were elderly patients. Diagnosis for stage III patients was predominantly serous EOC (48.6\%), while stage IV patients predominantly suffered from clear cell EOC (45.5\%). About half of the patients experienced optimal cytoreductive surgery, and two-third of cases underwent primary debulking surgery (PDS). Almost eighty percent of cases had no RD. Post-surgical chemotherapy was given in half of 
Table 1: Baseline characteristics of subjects $(n=48)$

\begin{tabular}{|c|c|c|c|}
\hline \multirow[t]{2}{*}{ Characteristics } & \multicolumn{2}{|c|}{ Total } & \multirow[t]{2}{*}{ Median (min-max) or Mean \pm SD } \\
\hline & $\mathrm{n}$ & $\%$ & \\
\hline Age (years) & - & & $51.9 \pm 8.9$ \\
\hline $31-40$ & 4 & 8.3 & \\
\hline $41-50$ & 18 & 37.5 & \\
\hline $51-60$ & 17 & 35.4 & \\
\hline$\geq 60$ & 9 & 18.8 & \\
\hline $\mathrm{BMI}\left(\mathrm{kg} / \mathrm{m}^{2}\right)$ & & & $24.5 \pm 3.6$ \\
\hline Underweight $(<18.5)$ & 2 & 4.2 & \\
\hline Normal (18.5-22.9) & 11 & 22.9 & \\
\hline Overweight (23-24.9) & 8 & 16.7 & \\
\hline Obese $(\geq 25)$ & 27 & 56.3 & \\
\hline \multicolumn{4}{|l|}{ Marital Status } \\
\hline Unmarried & 6 & 12.5 & \\
\hline Married & 42 & 87.5 & \\
\hline \multicolumn{4}{|l|}{ Age of Menarche (years) } \\
\hline$<12$ (early) & 0 & 0 & $13.5(12-15)$ \\
\hline $12-16$ & 48 & 100 & \\
\hline$\geq 16$ & 0 & 0 & \\
\hline Parity & & & $1.0(0-7)$ \\
\hline Nulliparity (0) & 16 & 33.3 & \\
\hline Primiparity (1) & 9 & 18.8 & \\
\hline Multiparity (>1) & 23 & 47.9 & \\
\hline \multicolumn{4}{|l|}{ Contraception History } \\
\hline Never use contraception & 43 & 89.5 & \\
\hline Injection & 2 & 4.2 & \\
\hline Intrauterine Device & 2 & 4.2 & \\
\hline Pill & 1 & 2.1 & \\
\hline Implant & 0 & 0 & \\
\hline Sterile & 0 & 0 & \\
\hline \multicolumn{4}{|l|}{ Menopausal Status } \\
\hline No & 25 & 52.1 & \\
\hline Yes & 23 & 47.9 & \\
\hline \multicolumn{4}{|l|}{ Histopathology of EOC } \\
\hline Serous & 22 & 45.8 & \\
\hline Non-Serous & 26 & 54.2 & \\
\hline Mucinous & 3 & 6.3 & \\
\hline Clear cell & 14 & 29.2 & \\
\hline Endometrioid & 1 & 2.1 & \\
\hline Seromucinous & 8 & 16.7 & \\
\hline \multicolumn{4}{|l|}{ FIGO staging } \\
\hline IIIA & 2 & 4.2 & \\
\hline IIIB & 3 & 6.3 & \\
\hline IIIC & 32 & 66.7 & \\
\hline IVA & 6 & 12.5 & \\
\hline IVB & 5 & 10.4 & \\
\hline
\end{tabular}

the patients; meanwhile, chemotherapy prior to surgery was administered in one-third of cases (thus having the management classified as NAC-IDS). Carboplatinpaclitaxel has become the primary regimen for chemotherapy. According to staging, a marked difference was noted in debulking surgery status ( $p<0.05)$, type of surgery $(p<0.01), \operatorname{RD}(p<0.01), \operatorname{RD}$ volume $(p<0.001)$, and use of NAC ( $p<0.05)$. Nevertheless, no difference was found in adjuvant administration and adjuvant chemotherapy cycles, and regimens were found.

The multivariate logistic regression analysis of several factors contributing to serous EOC is constructed in Table 3-menopausal status (OR $=4.82, \mathrm{p}<0.05$ ) became the only factor related to having advanced-stage serous ovarian cancer. Meanwhile, older age, which became a potential factor in the unadjusted model, was not statistically significant after multivariate analysis. Several factors predicting suboptimal debulking surgery are summarized in Table 4. Two significant predictors were serous EOC $(O R=8.25, p<0.01)$ and patients with stage IV EOC (OR = 11.13, p < 0.05).

Univariate analysis of 5 -year OS in Table 5 demonstrated no difference in median survival between age groups, obesity, staging, debulking status, debulking type, chemotherapy following surgery, adjuvant therapy, and histopathology subtype, except the RD $(p<0.01)$.
Table 2: Clinicopathological and profile treatments of subjects ( $n=48$ ) according to FIGO staging

\begin{tabular}{|c|c|c|c|c|c|c|c|}
\hline \multirow[t]{2}{*}{ Treatments profile } & \multicolumn{2}{|c|}{ Stage III } & \multicolumn{2}{|c|}{ Stage IV } & \multicolumn{2}{|c|}{ Total } & \multirow[t]{2}{*}{ p-value } \\
\hline & $\mathrm{n}$ & $\%$ & $\mathrm{n}$ & $\%$ & $\mathrm{n}$ & $\%$ & \\
\hline \multicolumn{8}{|l|}{ Age (years) } \\
\hline$<50$ & 16 & 43.2 & 4 & 36.4 & 20 & 41.7 & \multirow[t]{2}{*}{$0.741^{\mathrm{a}}$} \\
\hline$\geq 50$ & 21 & 56.8 & 7 & 63.6 & 28 & 58.3 & \\
\hline \multicolumn{8}{|l|}{ Histopathology of EOC } \\
\hline Serous & 18 & 48.6 & 4 & 36.4 & 22 & 45.8 & \multirow[t]{5}{*}{$0.465^{\mathrm{b}}$} \\
\hline Mucinous & 3 & 8.1 & 0 & 0.0 & 3 & 6.3 & \\
\hline Clear cell & 9 & 24.3 & 5 & 45.5 & 14 & 29.2 & \\
\hline Endometrioid & 6 & 16.2 & 2 & 18.2 & 8 & 16.7 & \\
\hline Seromucinous & 1 & 2.7 & 0 & 0.0 & 1 & 2.1 & \\
\hline \multicolumn{8}{|c|}{ Two Main Histopathology Subtypes of EOC } \\
\hline Serous & 18 & 48.6 & 4 & 36.4 & 22 & 45.8 & \multirow[t]{2}{*}{$0.473^{\mathrm{c}}$} \\
\hline Non-serous & 19 & 51.4 & 7 & 63.6 & 26 & 54.2 & \\
\hline \multicolumn{8}{|l|}{ Debulking Surgery Type } \\
\hline NAC-IDS & 7 & 18.9 & 8 & 72.7 & 15 & 31.2 & \multirow[t]{2}{*}{$0.002^{\mathrm{a}}$} \\
\hline PDS & 30 & 81.1 & 3 & 27.3 & 33 & 66.8 & \\
\hline \multicolumn{8}{|l|}{ Debulking Surgery Status } \\
\hline Optimal & 21 & 56.8 & 2 & 18.2 & 23 & 47.9 & \multirow[t]{2}{*}{$0.025^{\circ}$} \\
\hline Suboptimal & 16 & 43.2 & 9 & 81.8 & 25 & 52.1 & \\
\hline \multicolumn{8}{|l|}{ Presence of RD } \\
\hline No & 33 & 89.2 & 4 & 36.4 & 37 & 77.1 & \multirow[t]{2}{*}{$0.001^{\mathrm{a}}$} \\
\hline Yes & 4 & 10.8 & 7 & 63.6 & 11 & 22.9 & \\
\hline \multicolumn{8}{|l|}{ RD volume } \\
\hline No & 33 & 89.2 & 4 & 36.4 & 37 & 77.1 & \multirow[t]{4}{*}{$0.000^{b}$} \\
\hline Milliary/Microscopic & 1 & 2.7 & 1 & 9.1 & 2 & 4.2 & \\
\hline$<1 \mathrm{~cm}$ & 0 & 0.0 & 0 & 0.0 & 0 & 0 & \\
\hline$\geq 1 \mathrm{~cm}$ & 3 & 8.1 & 6 & 54.5 & 9 & 18.8 & \\
\hline \multicolumn{8}{|l|}{ NAC } \\
\hline Yes & 7 & 18.9 & 8 & 72.7 & 15 & 31.2 & $0.002^{\mathrm{a}}$ \\
\hline No & 30 & 81.1 & 3 & 27.3 & 33 & 68.8 & \\
\hline NAC Regimens & & & & & & & \\
\hline Carboplatin/Paclitaxel & 6 & 85.7 & 8 & 100 & 14 & 93.3 & $0.467^{\mathrm{a}}$ \\
\hline Carboplatin/Docetaxel & 1 & 14.3 & 0 & 0.0 & 1 & 6.7 & \\
\hline Number of NAC Courses & & & & & & & \\
\hline 3 & 3 & 42.9 & 5 & 62.5 & 8 & 53.3 & $0.377^{b}$ \\
\hline 4 & 1 & 14.3 & 2 & 25.0 & 3 & 20.0 & \\
\hline 5 & 2 & 28.6 & 0 & 0.0 & 2 & 4.2 & \\
\hline$\geq 6$ & 1 & 14.3 & 1 & 12.5 & 2 & 4.2 & \\
\hline Adjuvant Chemotherapy & & & & & & & \\
\hline Yes & 19 & 51.4 & 6 & 54.5 & 25 & 52.1 & $0.852^{\mathrm{c}}$ \\
\hline No & 18 & 48.6 & 5 & 45.5 & 23 & 47.9 & \\
\hline Adjuvant Chemotherapy $R$ & & & & & & & \\
\hline Carboplatin/Paclitaxel & 18 & 94.7 & 5 & 83.3 & 23 & 92.0 & $0.344^{\mathrm{b}}$ \\
\hline Carboplatin/Docetaxel & 1 & 5.3 & 0 & 0.0 & 1 & 4.0 & \\
\hline Gemcitabine/Oxaliplatin & 0 & 0.0 & 1 & 16.7 & 1 & 4.0 & \\
\hline Number of Adjuvant Chem & & & & & & & \\
\hline 3 & 4 & 25.0 & 2 & 40.0 & 6 & 28.6 & $0.774^{\mathrm{b}}$ \\
\hline 4 & 1 & 6.3 & 0 & 0.0 & 1 & 4.7 & \\
\hline 5 & 1 & 6.3 & 0 & 0.0 & 1 & 4.7 & \\
\hline$\geq 6$ & 10 & 62.5 & 3 & 60.0 & 13 & 62.0 & \\
\hline
\end{tabular}

NAC-IDS: NDadur cancer, RD: Residual disease, FIGO: International Federation of Gynecology and Obstetrics.

After performing analysis to create KaplanMeier curves, the overall 5-year survival analysis for stages III-IV EOC patients and subanalysis based on age, obesity status, and staging are depicted in Figure 1. The median follow-up in our study was 60 months. Median survival is 32 months, with OS being $37.5 \%$ for all stages III-IV EOC. For patients $<50$ years and $\geq 50$ years, the OS was $40 \%$ and $35.7 \%$, respectively, with a corresponding median survival of 39 and 29 months. The OS of obese patients was $37 \%$ compared to $38.1 \%$ in non-obese patients, with an equal median survival of 32 months. Stage III and IV EOC patients had OS $40.5 \%$ and $27.3 \%$, with 32 and 31 months median survival.

It can also be seen that the lines between groups of age status did not intersect the curve line. Thus the PH assumption was approved with HR 1.34 $(p=0.429)$. Meanwhile, both obesity status and staging groups intersect the line, so their curve does not meet the $\mathrm{PH}$ assumption.

Survival analysis was done between patients with optimal and suboptimal debulking surgery, as 
Table 3: Risk factors for serous carcinoma of advanced-stage EOC in histopathology

\begin{tabular}{|c|c|c|c|c|c|c|}
\hline \multirow[t]{2}{*}{ Factors } & \multicolumn{2}{|c|}{ Histopathology, n (\%) } & \multirow[t]{2}{*}{ Unadjusted OR (95\%Cl) } & \multirow[t]{2}{*}{$p$-value } & \multirow[t]{2}{*}{ Adjusted OR (95\%Cl) } & \multirow[t]{2}{*}{$\mathrm{p}$-value } \\
\hline & Non-Serous & Serous & & & & \\
\hline \multicolumn{7}{|l|}{ Age (years) } \\
\hline$<50$ & $15(57.7)$ & $5(22.7)$ & Ref & & Ref & \\
\hline$\geq 50$ & $11(42.3)$ & $17(77.3)$ & $4.64(1.31-16.42)$ & $0.014^{b}$ & $2.22(0.38-13.04)$ & $0.377^{\mathrm{d}}$ \\
\hline \multicolumn{7}{|l|}{ Obesity status } \\
\hline Obese & $15(57.7)$ & $12(54.5)$ & Ref & & - & \\
\hline Non obese & $11(42.3)$ & $10(45.5)$ & $1.14(0.36-3.57)$ & $0.827^{\mathrm{b}}$ & - & $\mathrm{n} / \mathrm{a}$ \\
\hline \multicolumn{7}{|l|}{ Marital Status } \\
\hline Unmarried & $5(19.2)$ & $1(4.5)$ & Ref & & Ref & \\
\hline Married & $21(80.8)$ & $21(95.5)$ & $5.00(0.54-46.53)$ & $0.199^{c}$ & $3.29(0.32-33.69)$ & $0.317^{\mathrm{d}}$ \\
\hline \multicolumn{7}{|l|}{ Parity } \\
\hline Nulliparous (0) & $11(42.3)$ & $5(22.7)$ & Ref & & Ref & \\
\hline Parrous ( $\geq 1$ ) & $15(57.7)$ & $17(77.3)$ & $2.49(0.70-8.83)$ & $0.152^{b}$ & $1.22(0.25-5.92)$ & $0.809^{d}$ \\
\hline \multicolumn{7}{|l|}{ Contraception History } \\
\hline Never use contraception & $24(92.3)$ & $19(86.4)$ & Ref & & - & \\
\hline Using contraception & $2(7.7)$ & $3(13.6)$ & $1.89(0.29-12.51)$ & $0.649^{b}$ & - & $\mathrm{n} / \mathrm{a}$ \\
\hline \multicolumn{7}{|l|}{ Menopausal status } \\
\hline No & $18(69.2)$ & $7(31.8)$ & Ref & & Ref & \\
\hline Yes & $8(30.8)$ & $15(68.2)$ & $4.82(1.42-16.40)$ & $0.010^{\mathrm{b}}$ & $4.82(1.42-16.40)$ & $0.012^{\mathrm{d}}$ \\
\hline
\end{tabular}

seen in Figure 2. The OS patients undergoing optimal compared to suboptimal debulking surgery were $43.5 \%$ versus $32 \%$, with a median survival of 39 and 29 months with HR was 1.45 ( $p=0.316)$. Furthermore, the OS patients undergoing NAC-IDS compared to PDS were $46.7 \%$ versus $31.3 \%$, with a median survival of 41 and 29 months, respectively, and HR was $1.57(p=0.277)$. Moreover, the OS and median survival in patients with the RD was $9.1 \%$ and 39 months, compared to no RD was $45.9 \%$ and 2 months.

According to Figure 3, the OS for the patient given adjuvant therapy was $40 \%$ compared to $34.8 \%$ for those without adjuvant, HR 1.38 ( $p=0.380)$. The median survival respectively were 39 and 29 months. The deep analysis concerning debulking surgery combined with chemotherapy, patients who underwent optimal debulking surgery, followed by adjuvant chemotherapy, obtained an OS of $40 \%$. In contrast, patients who were not given adjuvant chemotherapy obtained a higher 5 -year survival of $46.2 \%$, with a median survival of 32 months and 39 months. Patients who underwent suboptimal debulking surgery following adjuvant chemotherapy obtained an OS rate of $40 \%$ and $20 \%$ in patients not given, with a median survival of 39 months and 2 months, respectively.

In Figure 4, patients with seromucinous EOC obtained a 5 -year OS of $100 \%$, while for serous, mucinous, endometrioid, and clear cells ovarian cancer, respectively, the OS was 50\%, 33.3\%, 25\%, and $21.4 \%$. Due to the lack of samples for seromucinous ovarian cancer, the analysis of median survival rate excluded the case with seromucinous EOC. The median survival of serous, mucinous, clear cells and endometrioid EOC cases were $39,45,31$, and 24 months, respectively. Moreover, comparing the two main subtypes, serous and non-serous subtypes had an OS rate and median survival of $50 \%$ versus $24 \%$ and 39 months versus 29 months, respectively.

In Table 6, variables that meet the $\mathrm{PH}$ assumption were included in bivariate analysis. Only $\mathrm{RD}$ becomes a significant independent prognostic factor to include in multivariate analysis $(p<0.25)$. The HR value was $3.50(p<0.01)$

\section{Discussion}

\section{Demographic and risk factors}

The incidence of EOC increases with age and varies with race [15]. However, the clinicopathological features of EOC have rarely been reported in the Asia-Pacific region and were restricted to reports

Table 4: Predictors for suboptimal debulking surgery

\begin{tabular}{|c|c|c|c|c|c|c|}
\hline \multirow[t]{2}{*}{ Factors } & \multicolumn{2}{|c|}{ Debulking Surgery, n (\%) } & \multirow[t]{2}{*}{ Unadjusted OR (95\%Cl) } & \multirow[t]{2}{*}{$\mathrm{p}$-value } & \multirow[t]{2}{*}{ Adjusted OR $(95 \% \mathrm{Cl})$} & \multirow[t]{2}{*}{$p$-value } \\
\hline & Optimal & Suboptimal & & & & \\
\hline \multicolumn{7}{|l|}{ Age (years) } \\
\hline$<50$ & $11(47.8)$ & $9(36.0)$ & Ref & & - & \\
\hline$\geq 50$ & $12(52.2)$ & $16(64.0)$ & $1.63(0.51-5.18)$ & $0.406^{\mathrm{b}}$ & - & $n / a$ \\
\hline \multicolumn{7}{|l|}{ Obesity status } \\
\hline Non obese & $13(56.5)$ & $14(56.0)$ & Ref & & - & \\
\hline Obese & $10(43.5)$ & $11(44.0)$ & $1.02(0.33-3.20)$ & $0.971^{\mathrm{b}}$ & - & $\mathrm{n} / \mathrm{a}$ \\
\hline \multicolumn{7}{|l|}{ Histopathology } \\
\hline Non-Serous & 17 (73.9) & $9(36.0)$ & Ref & & Ref & \\
\hline Serous & $6(26.1)$ & $16(64.0)$ & $5.04(1.46-17.38)$ & $0.008^{b}$ & $8.25(1.96-34.63)$ & $0.004^{d}$ \\
\hline \multicolumn{7}{|l|}{ FIGO Stage } \\
\hline III & $21(91.3)$ & $16(64.0)$ & Ref & & Ref & \\
\hline IV & $2(8.7)$ & $9(36.0)$ & $5.91(1.12-31.20)$ & $0.025^{\mathrm{b}}$ & $11.13(1.71-72.70)$ & $0.012^{d}$ \\
\hline \multicolumn{7}{|l|}{ NAC use } \\
\hline No & $18(78.3)$ & $15(60.0)$ & Ref & $0.173^{b}$ & Ref & $0.912^{\mathrm{d}}$ \\
\hline Yes & $5(21.7)$ & $10(40.0)$ & $2.40(0.67-8.58)$ & & $0.91(0.16-5.03)$ & \\
\hline
\end{tabular}


from Western regions. Thus, we compiled a dataset from a leading referral hospital in Indonesia during a 7-year study. The results may allude to the distinctive characteristics of the southeast Asian populations regarding ovarian cancer. Our study observed that demographic profiles acting as predisposing factors to ovarian cancer include: age, BMI, marital status, age of menarche, parity, contraception history, contraception use, and menopausal status.

Table 5: Univariate analysis of overall survival based on clinicopathological characteristics and treatment profiles

\begin{tabular}{|c|c|c|c|c|c|}
\hline Characteristics & $\begin{array}{l}\text { Total, } \\
\mathrm{n}\end{array}$ & $\begin{array}{l}\text { Death } n \\
(\%)\end{array}$ & $\begin{array}{l}\text { Mean } \\
\text { survival } \\
\text { (months) }\end{array}$ & $\begin{array}{l}\text { Median } \\
\text { survival } \\
\text { (months) }\end{array}$ & $\mathrm{p}$-valuea \\
\hline Overall cases & 48 & $30(62.5)$ & 34.13 & 32.00 & \\
\hline \multicolumn{6}{|l|}{ Age Groups (years) } \\
\hline$<50$ & 20 & $12(60.0)$ & 39.00 & 39.00 & \multirow[t]{2}{*}{0.419} \\
\hline$\geq 50$ & 28 & $18(64.3)$ & 30.64 & 29.00 & \\
\hline \multicolumn{6}{|l|}{ Obesity status } \\
\hline Non obese & 21 & $13(61.9)$ & 33.95 & 32.00 & \multirow[t]{2}{*}{0.940} \\
\hline Obese & 27 & $17(63.0)$ & 34.26 & 32.00 & \\
\hline \multicolumn{6}{|l|}{ FIGO Staging } \\
\hline III & 37 & $22(59.5)$ & 35.27 & 32.00 & \multirow[t]{2}{*}{0.441} \\
\hline IV & 11 & $8(72.7)$ & 30.27 & 31.00 & \\
\hline \multicolumn{6}{|l|}{ Debulking Surgery Type } \\
\hline NAC-IDS & 15 & $8(53.3)$ & 40.67 & 41.00 & \multirow[t]{2}{*}{0.212} \\
\hline PDS & 32 & $22(68.7)$ & 30.25 & 29.00 & \\
\hline \multicolumn{6}{|l|}{ Debulking Surgery Status } \\
\hline Optimal & 23 & $13(56.5)$ & 37.52 & 39.00 & \multirow[t]{2}{*}{0.304} \\
\hline Suboptimal & 25 & $17(68.0)$ & 31.00 & 29.00 & \\
\hline \multicolumn{6}{|l|}{ Debulking Surgery } \\
\hline Interval, Optimal & 5 & $2(40.0)$ & 45.00 & 31.00 & \multirow[t]{4}{*}{0.369} \\
\hline Interval, Suboptimal & 10 & $6(60.0)$ & 38.50 & 32.00 & \\
\hline Primary, Optimal & 18 & $11(61.1)$ & 35.44 & 26.00 & \\
\hline Primary, Suboptimal & 15 & 11 (73.3) & 26.00 & 32.00 & \\
\hline \multicolumn{6}{|l|}{ Presence of RD } \\
\hline No & 37 & $20(54.1)$ & 39.70 & 39.00 & \multirow{2}{*}{0.001} \\
\hline Yes & 11 & $10(80.9)$ & 15.36 & 2.00 & \\
\hline \multicolumn{6}{|l|}{ Adjuvant Chemotherapy Post } \\
\hline Debulking Surgery & & & & & \\
\hline $\begin{array}{l}\text { Optimal debulking continue with } \\
\text { adjuvant therapy }\end{array}$ & 10 & $6(60.0)$ & 36.20 & 32.00 & \multirow[t]{4}{*}{0.086} \\
\hline $\begin{array}{l}\text { Optimal debulking without adjuvant } \\
\text { therapy }\end{array}$ & 13 & $7(53.8)$ & 38.54 & 39.00 & \\
\hline $\begin{array}{l}\text { Suboptimal debulking continue } \\
\text { with adjuvant therapy }\end{array}$ & 15 & $9(60.0)$ & 39.47 & 39.00 & \\
\hline $\begin{array}{l}\text { Suboptimal debulking without } \\
\text { adjuvant therapy }\end{array}$ & 10 & $8(80.0)$ & 18.30 & 2.00 & \\
\hline \multicolumn{6}{|l|}{ Adjuvant Chemotherapy } \\
\hline Yes & 25 & $15(60.0)$ & 38.16 & 39.00 & \multirow[t]{2}{*}{0.369} \\
\hline No & 23 & $15(65.2)$ & 29.74 & 29.00 & \\
\hline \multicolumn{6}{|l|}{ Histopathology of EOC } \\
\hline Serous & 22 & $11(50.0)$ & 37.41 & 39.00 & \multirow[t]{5}{*}{0.470} \\
\hline Mucinous & 3 & $2(66.7)$ & 39.00 & 45.00 & \\
\hline Clear cell & 14 & $11(78.6)$ & 29.07 & 31.00 & \\
\hline Endometrioid & 8 & $6(75.0)$ & 28.88 & 24.00 & \\
\hline Seromucinous & 1 & $0(0)$ & $\mathrm{n} / \mathrm{a}$ & $\mathrm{n} / \mathrm{a}$ & \\
\hline \multicolumn{6}{|l|}{$\begin{array}{l}\text { Two Main Histopathology Subtypes } \\
\text { of EOC }\end{array}$} \\
\hline Serous & 22 & $11(50.0)$ & 37.41 & 39.00 & \multirow[t]{2}{*}{0.155} \\
\hline Non-serous & 25 & $19(76.0)$ & 30.20 & 29.00 & \\
\hline
\end{tabular}

\section{Age}

Subjects ranged from 32 to 68 years old (mean $51.9 \pm 8.9$ years). Globally, ovarian cancer cases are predominantly diagnosed in the elderly. EOC is an agerelated disease and is primarily postmenopausal [16]. However, in our study, most patients were still in their productive age with equal proportion for menopausal status groups. We found younger age incidences of EOC than in other developing countries, such as 52.3 years in Thailand [17] and 53 years in China [18]. The discrepancy in the age at diagnosis involves the influence of race/ethnicity on hormonal and cancer attributes, along with histological subtypes [19].

\section{Obesity}

In addition, more than half of our patients were obese, which corresponded to an increased chance of getting ovarian cancer, related to the transformation of androgen in the peripheral tissues [2]. Our result is consistent with prior studies, in which, using the same BMI cut-off for the Asian population, investigators yielded a result EOC patients suffering from obesity of $41.4 \%$ proportion in Indonesia [20] and 32\% proportion in Thailand [17]. Rodriguez et al. [21] wrote on a $36 \%$ increase in the chance of ovarian cancer among women with obesity.

\section{Marital status}

Most patients were married and multiparous in the current study, similar to a prior study [22], but showed no statistically significant difference with a proportion similar to the Thailand population $(71.5 \%)$ [17]. According the reference unmarried women are nulliparous and associated with a condition of continuous ovulation, which increases the likelihood of ovarian malignancy $(\mathrm{OR}=1.13)$ [23].

\section{Age of menarche}

In this study, all patients had a history of menarche within the typical age range, consistent with the average menarche age in Indonesia was 12-16 years [24]. Our study followed the definition of early menarche as menarche before 12 years [25] and late menarche as menarche at 16 years or above [26]. Several analyses revealed an association between the early start of menarche and the chance of ovarian cancer [27], [28]; meanwhile, others inferred a less powerful association between the risk of ovarian cancer and menarche onset [29], [30]. Early menarche is related to an earlier start of the ovulatory cycles and, reflecting pubertal hormonal levels, manages to maintain higher luteal phase estradiol and progesterone [29]. Women with delayed age at menarche may have additional years of low-level estrogen and progesterone inciting their ovarian epithelium, diminishing the chance of the cells acquiring genetic damage [29].

\section{Parity}

Thirty-three percent of our study are nulliparous women, similar to proportions from a study in Thailand (35.5\%) [17]. A study stated that nulliparous individuals carried a $24 \%$ higher chance of ovarian cancer than multiparous women, with a $68 \%$ higher risk of clear cell EOC [31]. Nulliparity also relates to infertility, 

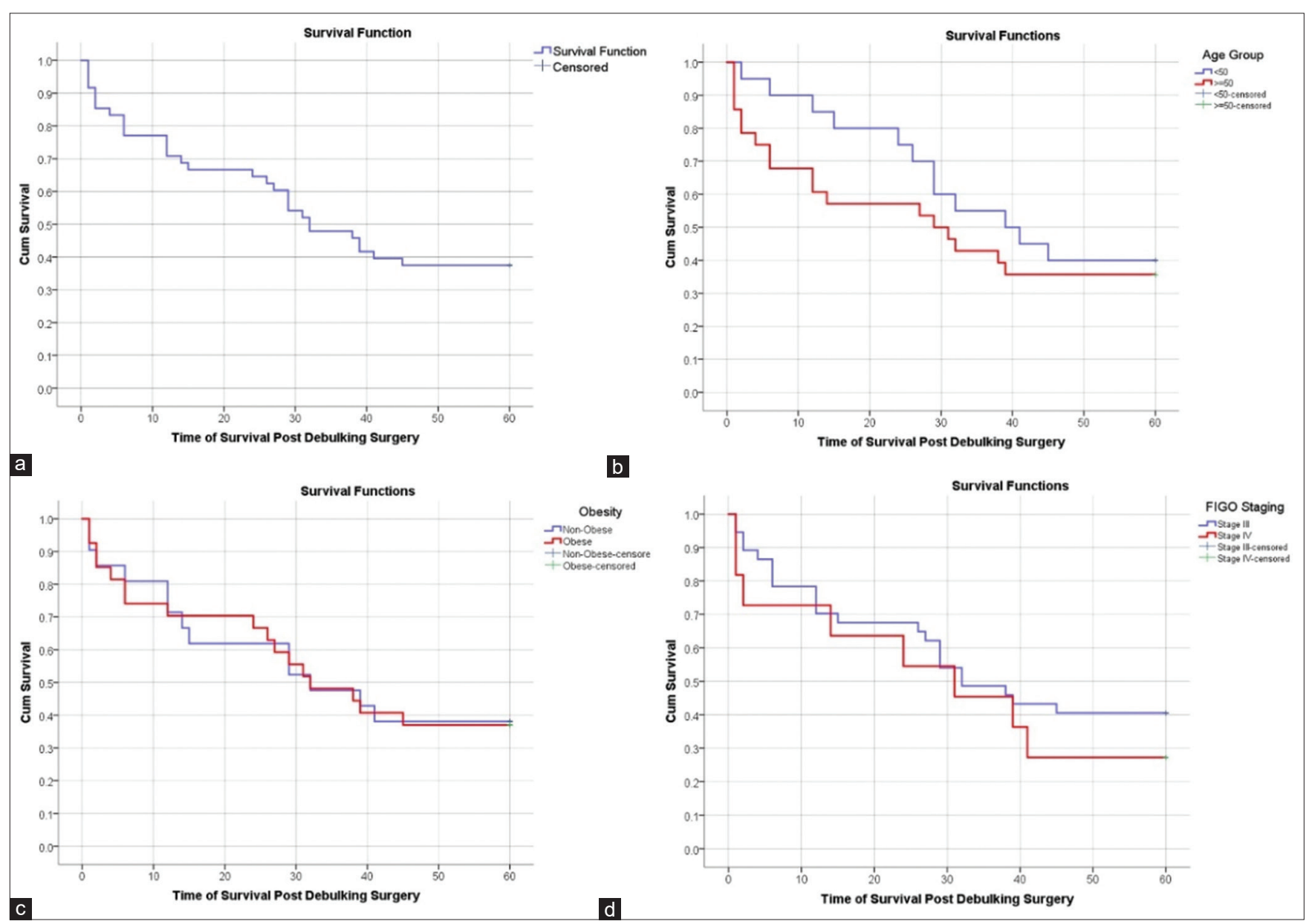

Figure 1: Kaplan Meier curve of 5-year overall survival for (a) advanced-stage epithelial ovarian cancer in general, (b) based on age, (c) according to obesity status, (d) based on FIGO staging in a tertiary hospital, Indonesia

with the adjusted HR of ovarian cancer being 1.53 , corresponding to fertile women [18]. This association suggested several mechanisms, including enhanced oxidative stress provoked by retrograde menstruation and microenvironmental transformations that facilitates carcinogenesis [32]. This is also supported by the idea of incessant ovulation, noting that ovarian epithelial deterioration occurs over time when ovulation emerges, directing to neoplastic transformation. This view explains why patients with parity are submitted to half the risk of having ovarian cancer due to the cancellation of continuous ovulatory cycles [33]. Pregnancy suppresses pituitary gonadotropin secretion [34], and there might be a pause in the ovulation cycles and an upsurge in progesterone hormone, yielding a protective impact against ovarian cancer [35]. Pregnancy and lactation may interfere with the pro-inflammatory environment of an endless ovulation cycle by altering the hormonal environment or removing pre-cancerous cells from the ovary [36].

\section{Contraception}

The risk of ovarian cancer grew among nonusers of oral contraceptives (OCs) [37]. Hormonal contraceptives offered a protective impact on ovarian cancer by confining repeated ovulation cycles [36], thus preventing the mutation of the p53 gene in carcinogenesis [38]. The three common contraceptives methods used among women in our study were injection, intrauterine device (IUD), and OCs. Although OCs are potent against ovarian cancer, it is vague how long it lasts. There was a $38 \%$ reduction in the new cases of ovarian cancer with $\geq 10$ years of OCs use [37]. Moreover, OCs reduce endogenous androgen and estrogen levels but increase circulating progesterone levels [34]. Opposing OCs, IUD users were reported to show an increased risk for experiencing ovarian cancer against non-users $(R R=1.76)$. IUD was correlated with the occurrence of serous $(R R=2.17)$ and endometrioid $(R R=2.40)$ EOCs [37]. IUD may boost peritoneal inflammation, augmenting the chance of ovarian cancer [39].

\section{Menopausal status}

Ovarian cancer is most frequently diagnosed in postmenopausal women, possibly due to estrogen transducing the pro-metastatic pathways via nuclear estrogen receptors (ER) [40], particularly in those who received estrogen. After menopause, a transformation occurred in the proportions of the two sex hormones 

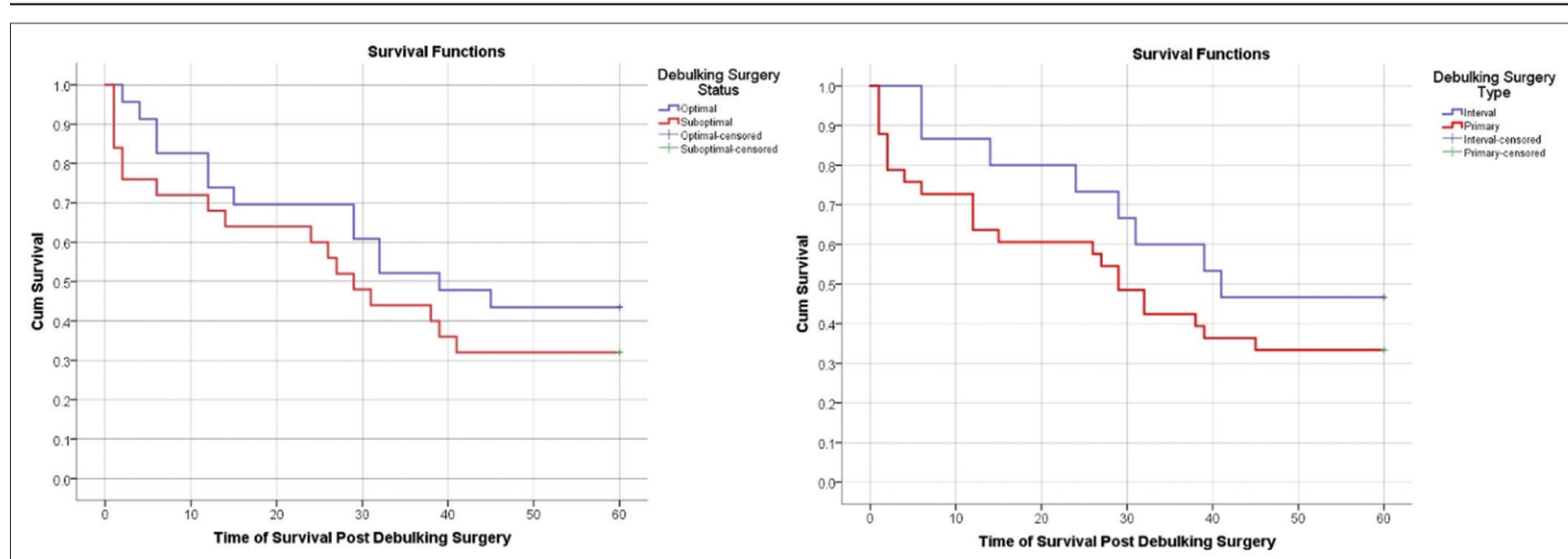

a

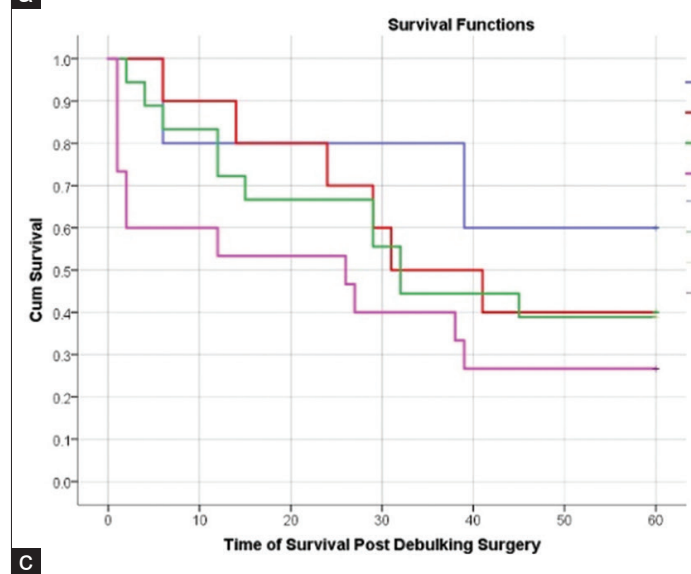

b

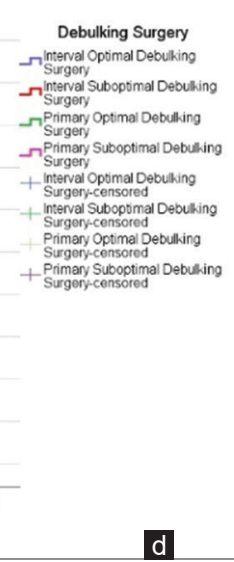

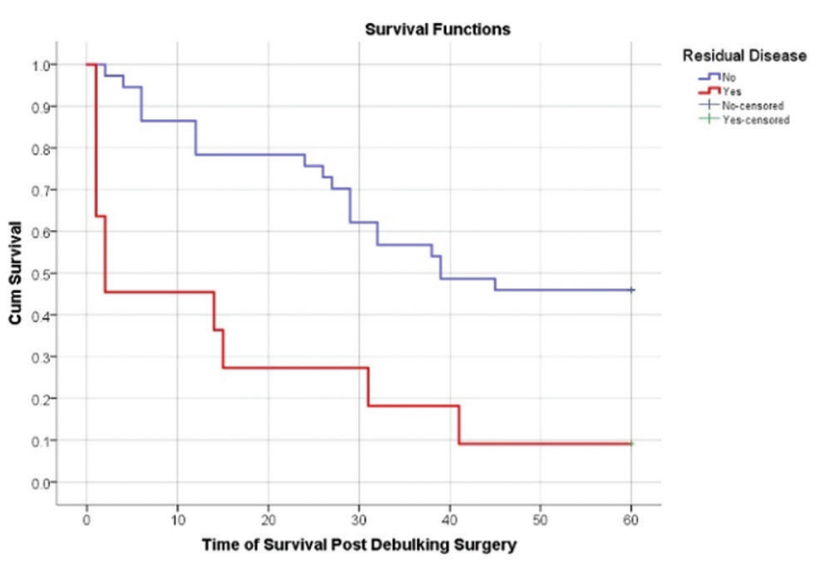

Figure 2: Kaplan Meier curve of 5-year overall survival regarding (a) debulking surgery status, (b) debulking surgery type, (c) debulking surgery status and type, and (d) presence of residual disease

directing more estrogen levels, increasing the chance of conceiving ovarian cancer [41]. Nevertheless, in our research, the proportion of premenopausal women was higher than menopausal women with EOC, possibly due to fewer samples or ethnic differences in hormonal, cancer, and histology characteristics similar to prior Asian studies [19]. Moreover, menopause is more related to age (>50 years) and does not directly cause ovarian cancer [41].

\section{Stage differences}

According to the FIGO staging classification, most subjects entering this study were in stage IIIC $(66.7 \%)$, similar to a prior study in Bandung, Indonesia, in 2019 [20]. More than 50\% were elderly patients. The number of cases with FIGO stage III-IV in both groups was higher than previous studies, which discovered that $90 \%$ of older women with ovarian cancer had an advanced-stage disease [42]. Comparing the five subtypes, most serous EOC patients were diagnosed at an advanced-stage due to generally being asymptomatic [43]. Patients with stage III were more often diagnosed with serous subtype than clear cell EOC in which more common in stage IV EOC. Literature proved that clear cell or mucinous tumors were more common in stage IV and were found with a remarkably worse prognosis than other histologic subtypes [44]. Moreover, patients with clear cell tumors are more likely to be Asian [45]. Patients with PDS were more often stage III than patients who got NAC-IDS, which was higher in stage IV. The level of primary cytoreduction accomplished is conceivably the most crucial prognostic factor impacting the eventual destiny of the patient [46]. Of those who underwent primary cytoreductive surgery, optimal cytoreduction was achieved in $47.9 \%$. Suboptimal debulking surgery was significantly more often undergone by stage IV patients with EOC than stage III. The extent and complication of the surgery are directly commensurate with the cancer stage. Advanced cancers have a reduced likelihood of surgery success due to multiple metastatic foci, which often averts complete cytoreduction [40]. A complete gross resection to no macroscopic RD was accomplished in $77.1 \%$ of cases. RD was significantly greater in stage IV with $\geq 1 \mathrm{~cm}$ in volume. In the present study, of the 48 patients, two-third of cases underwent primary cytoreductive surgery, and $31.2 \%$ received NACIDS. Patients with stage IV EOC more often use NAC protocols. Patients commonly experience 4-5 cycles of chemotherapy [47], meanwhile in our study, in both stages (III and IV), the most common number of NAC cycles was three, and adjuvant chemotherapy cycles were $\geq 6$. 


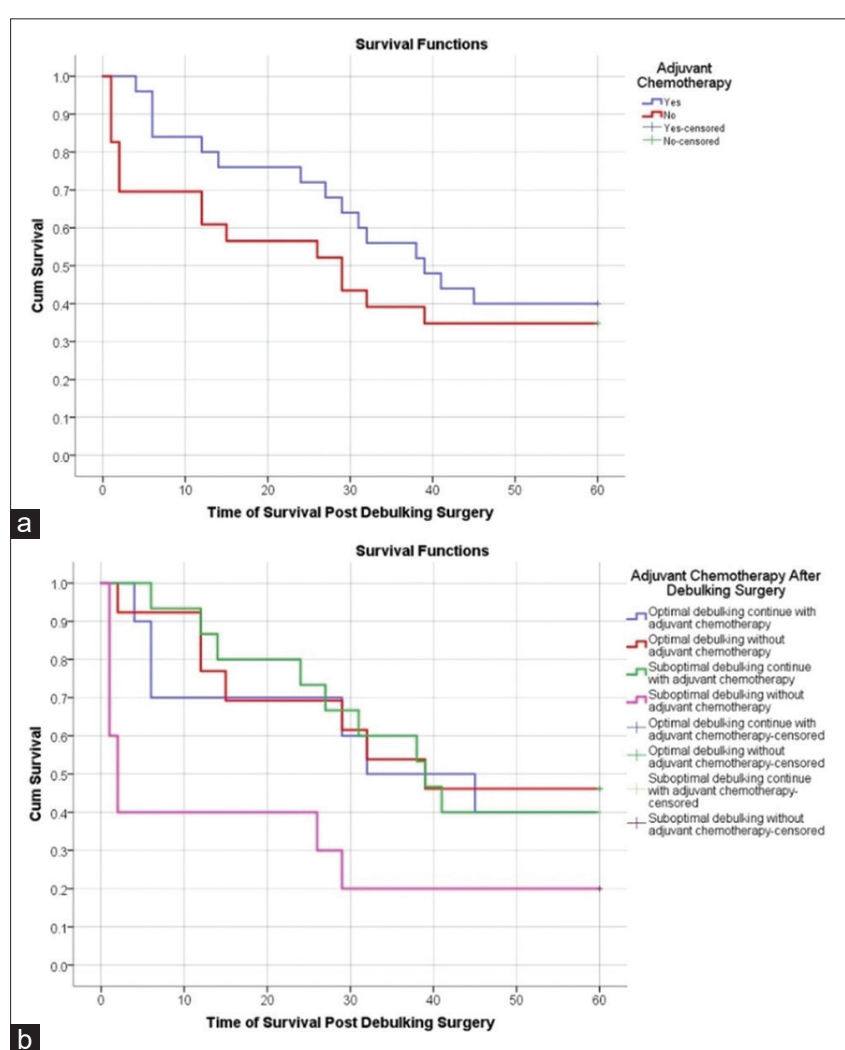

Figure 3: Kaplan Meier curve of 5-year overall survival based on (a) administration of adjuvant chemotherapy without consideration of debulking surgery, and (b) with considering debulking surgery

\section{Histopathology subtypes risk factor}

In histopathology, $90 \%$ of ovarian tumors are thought to have arisen via the change of fallopian tube epithelial cells rather than those deriving from germ cells or sex-cord-stromal tissues; thus, most of these cancers are designated as EOC [46]. Among EOC subtypes, we found serous EOC becoming prevalent. This finding was corroborated by the Asian incidence [48]. The incidence of clear cell subtype is $25 \%$ of all EOC in Asia, similar to our result, but only $<10 \%$ in Western countries [49]. It could be due to ethnic differences between Western and Asian populations.

Former investigations have documented inconsistent results for the risk factors analyses among each histologic subtype of ovarian cancer, possibly arising from geographic and ethnicity disparity or sampling matters discrepancy. In univariate analysis, we observed two significant independent risk factors for serous EOC: age and menopausal status, but in the adjusted model, only menopausal status significantly became a risk factor for serous EOC $(\mathrm{OR}=4.82$ 95\%Cl: $1.42-16.40, \mathrm{p}=0.012)$. A Chinese study confirmed that serous EOC was diagnosed significantly greater in postmenopausal (62\%) compared to premenopausal patients (38\%) [19].

Our results showed that age, obesity, marital status, parity, and contraception use were not statistically associated with increased risks for serous EOC, both in unadjusted and adjusted models. Comparing the age

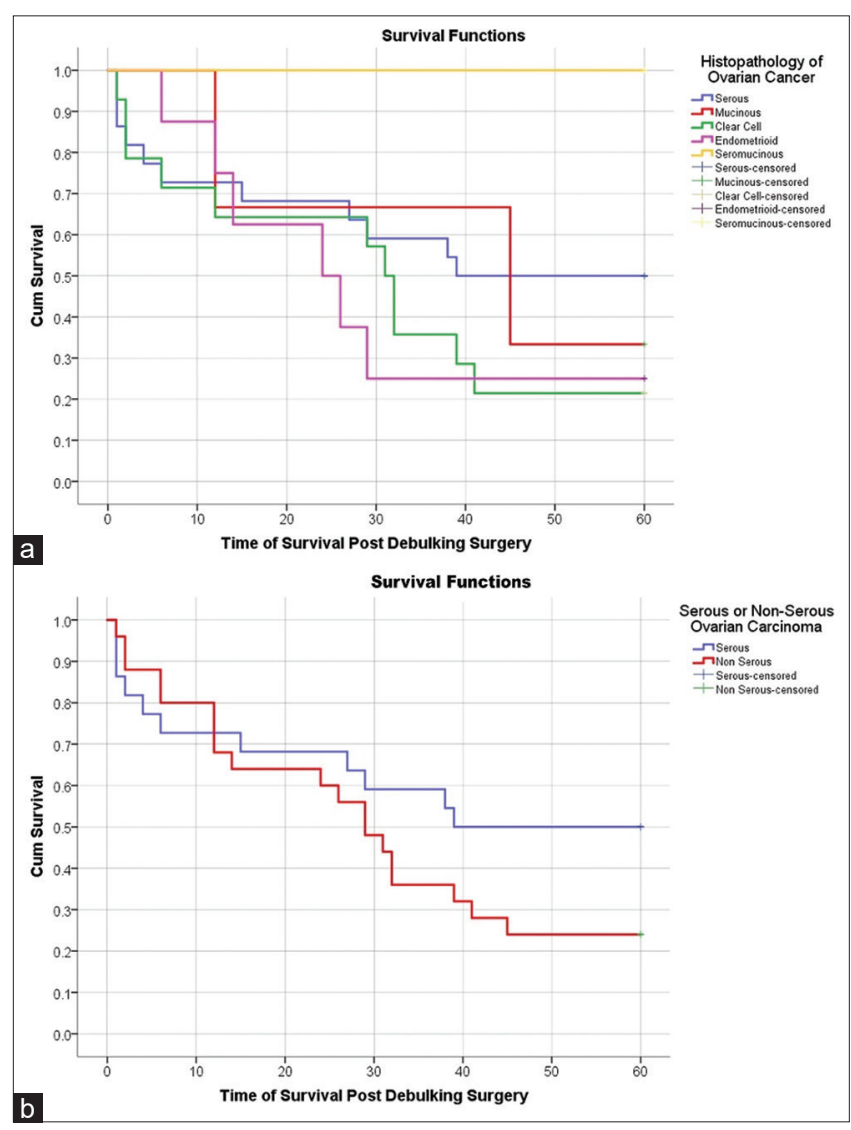

Figure 4: Kaplan Meier curve of 5-year overall survival according to (a) all histopathology results and (b) serous compared non-serous ovarian cancer

of women diagnosed with serous and non-serous EOC, we found that serous subtype tended higher in the aging and parous population, agreeing with the prior study [50]. Aging and menopause have been linked with a possible expanded chance of getting serous EOC [46], [51], [52]. Meanwhile, similar to former studies, the obesity or BMI score was not statistically essential as a risk factor for serous EOC [50], [53]. Moreover, in our report, the variables related to the hormonal status were not a significant risk to serous EOC because this subtype had weaker connections to most reproductive factors than with non-serous EOC. It was analogous with hormone receptor-negative breast cancers theory [50], [54].

\section{Suboptimal debulking surgery predictors}

We constructed a logistic model to predict the suboptimal surgical cytoreduction. The results showed that serous EOC $(O R=8.25)$ and FIGO staging $(O R=11.13)$ significantly enhanced the chance to experience suboptimal surgical cytoreduction. The prior study reaffirmed that subtype [55], particularly serous EOC [56] and stage of disease [55], [57], were associated significantly and became predictors to suboptimal debulking surgery. In Thailand, advancedstage became a significant predictor for suboptimal surgery $(\mathrm{OR}=4.78, \mathrm{p}<0.001)[17]$. 
Table 6: Identification of prognostic factors using Cox regression analysis for overall survival in $\mathbf{4 8}$ subjects with advanced-stage EOC

\begin{tabular}{|c|c|c|c|c|c|c|}
\hline \multirow[t]{2}{*}{ Prognostic factors } & \multicolumn{3}{|c|}{ Bivariate } & \multicolumn{3}{|c|}{ Multivariate } \\
\hline & $\overline{H R}$ & $95 \% \mathrm{Cl}$ & $p$-value & $\mathrm{HR}$ & $95 \% \mathrm{Cl}$ & $\mathrm{p}$-value \\
\hline \multicolumn{7}{|l|}{ Age (years) } \\
\hline$<50$ & Ref & & & - & & \\
\hline$\geq 50$ & 1.34 & $0.65-2.79$ & 0.429 & - & - & $\mathrm{n} / \mathrm{a}$ \\
\hline \multicolumn{7}{|c|}{ 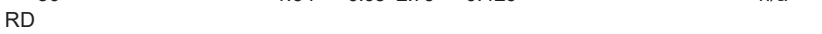 } \\
\hline No & Ref & & & Ref & & \\
\hline Yes & 3.50 & $1.62-7.58$ & 0.001 & 3.50 & $1.62-7.58$ & 0.001 \\
\hline \multicolumn{7}{|c|}{ Debulking Surgery Status } \\
\hline Optimal & Ref & & & - & & \\
\hline Suboptimal & 1.45 & $0.70-2.98$ & 0.316 & - & - & $\mathrm{n} / \mathrm{a}$ \\
\hline \multicolumn{7}{|c|}{ Debulking Surgery Type } \\
\hline NAC-IDS & Ref & & & - & & \\
\hline PDS & 1.57 & $0.70-3.52$ & 0.277 & - & - & $\mathrm{n} / \mathrm{a}$ \\
\hline \multicolumn{7}{|c|}{ Adjuvant Chemotherapy } \\
\hline Yes & Ref & & & - & & \\
\hline No & 1.38 & $0.67-2.82$ & 0.380 & - & - & $\mathrm{n} / \mathrm{a}$ \\
\hline
\end{tabular}

We found that age did not significantly differ among two groups of debulking surgery, similar to prior study [57]. In contrast, a multivariate analysis from $\mathrm{Gu}$ et al. [58] found age $>60$ years become a significant predictor for suboptimal debulking surgery with $O R$ 2.39 possibly due to younger cut-off of elderly we used in this study. Other variables such as obesity were not significant predictors of suboptimal debulking surgery in contrast with Suknikhom et al. [17]. Furthermore, we did not find the significance of NAC use as a risk for suboptimal surgery, although a meta-analysis by Kang et al. [59] revealed that patients who had gone with the NAC procedure had a smaller chance to undergo suboptimal cytoreduction.

\section{Overall Survival}

In this present research, we obtained the 5 -year OS and median survival of advanced-stage EOC in Indonesia is similar to literature, $30-46 \%$ for OS [60] and 33-43 months for median survival [61]. Furthermore, we evaluated the 5-year OS regarding age, obesity status, staging, debulking type, debulking status, RD, chemotherapy, and histopathology.

\section{Correlation between OS and age}

Advanced age has been established as an unfavorable prognostic factor affecting the OS of EOC [62], [63], [64]. Elderly patients were distinguished by high-grade tumor, low performance levels, and undertreatment [42]. Furthermore, fragile geriatrics with EOC probably do not experience aggressive debulking surgery and standard chemotherapy [65], [66]. Lower survival among old patients is also ascribed to transformations in tumor biological attributes and innate resistance to chemotherapy [67]. In Wimberger et al. [63], the lack of residual tumor after PDS was frequently accomplished in the younger individuals, impacting a higher median survival with 27.5 months difference than the same parameter in the elderly. We also observed a 10-month difference in median survival between young and old patients. Meanwhile, the OS of older patients tended to be shorter than their younger counterparts, though it is not statistically meaningful. This was possible because of different age cut-offs used in various studies. Age remains controversial as an essential prognostic factor for OS because aging is more related to comorbidities [68]; yet, we excluded comorbidities in this study.

\section{Correlation between OS and obesity}

This study suggests that EOC patients with obesity had slightly worse survival than non-obese patients though not statistically significant. This is consistent with literature that shows that obesity diminishes survival in ovarian cancer with $\mathrm{HR}=$ 3.40 [21]. Moreover, we did not find BMI or obesity status as a reliable prognostic factor agreeing with Kotsopoulos et al. [69], confirming height, weight, and adiposity were unrelated to ovarian cancer prognosis.

\section{Correlation between OS and staging}

Stage III EOC had a slightly longer median survival and higher OS than stage IV in our study, though the data was not statistically meaningful. The 5 -year OS rate (27.3\%) and median survival (31 months) of our stage IV patients were similar to a Japanese study (27.9\% and 30.8 months, respectively) [45]. The insignificant OS according to FIGO staging was similar to a prior study [70]. In this study, we did not perform analysis on the FIGO sub-staging in more detail (IIIAIVB) because of the few patients for each stage. The influence of FIGO substages was found in a Norwegian study as an independent prognostic factor for OS but only for those who underwent optimal debulking surgery [70]; meanwhile, not all subjects have achieved it in our study.

\section{Correlation between OS and type of surgery}

We also demonstrated that the OS of patients undergoing NAC-IDS was $15.4 \%$ higher, and median survival was 12 months longer than PDS, although the difference was not statistically significant. These patients were managed with the first three rounds of chemotherapy, followed by an interval at which patients experience surgical cytoreduction and ultimately the remaining three cycles of chemotherapy [71]. The insignificant difference in result for PDS and NAC-IDS was consistent with former research that NAC-IDS (29 versus 41 months, respectively) did not translate into a substantial advancement of median survival (22.6 versus 24.1 months, respectively) [64]. Randomized trials have indicated that NAC-IDS in individuals with advanced-stage ovarian cancer proffered an equal chance of survival as PDS in terms of OS [44], [62], but less morbidity was reported after NAC [44]. Furthermore, extensive PDS practices are related to tremendous 
morbidity, mortality, and declined quality of life. Thus, individuals who experience suboptimal debulking may incur substantial morbidity without an associated gain in survival after PDS [72]. Although not statistically significant, the supposed additional 1 year of survival seems clinically beneficial. NAC-IDS will be impactful if optimal debulking could be achieved [22], and that $50 \%$ of patients would achieve around 52.5 months of survival with optimal cytoreduction after NAC-IDS compared to 24.2 if the surgery were suboptimal [73].

We can not precisely answer why NAC-IDS patients in our cohort tended to have more prolonged median survival than PDS, but this was possibly due to the included patients' clinical condition in this cohort. Probably, our population may have a more significant proportion of patients with chemosensitive tumors than resistant groups similar to a prior study [45]. Also, our patients with advanced EOC could benefit from NACIDS due to their poor performance status, concurrent morbidity, or elder age [64]. Moreover, NAC-IDS would be advantageous for patients whose PDS was not executed beneath optimal situations or by a gynecologic oncologist [64]. NAC will improve the feasibility of optimal surgery by decreasing tumor spread [59]. NAC-IDS is less extensive, has minor blood loss, reduces morbidity rates, decreases hospital length stay, and improves the quality of life. It also assists in identifying platinumresistant malignant cells by recognizing patients who do not respond to earlier chemotherapy and may not benefit from additional surgery [11]. The other indication is ovarian cancer stage IIIC with ascites $>500$ cc [22]. Van der Burg et al. also found that OS is enhanced in subjects who had subsequent surgery. The median survival in individuals with optimal NAC-IDS was equal to those who underwent suboptimal debulking at PDS (19.4 vs. 20 months) [74], corroborating our results in Table 5 (32 vs. 32 months).

The contribution of NAC to survival is not clear in the current literature. Still, there is only scarce evidence that NAC-IDS is superior to PDS. A study previously discussed the benefit of initial chemotherapy to reduce the size of the tumor [75]. However, patients are more exposed to generating mutations and cultivating chemoresistance because of the enormous tumor burden exposure to chemotherapy agents in NAC-IDS courses, thus leaving behind chemoresistant cells [11], [76]. Rauh-Hain et al. found that $88.8 \%$ of patients who underwent NAC-IDS were deemed platinum-resistant (with recurrence within 6 months), comparing that $55.3 \%$ in the group experienced PDS $(p<0.001)$ [77]. Table 4 demonstrated that NAC use has not increased the optimal debulking surgery rate and has not significantly improved OS. This might be due to the dose-density effect's violation by interrupting chemotherapy with NAC-IDS [64], [78]. Although chemotherapy continually reduces the volume of $\mathrm{RD}$, it sometimes deforms tissue planes, and henceforth, the complete debulking at NAC-IDS may be restricted [11].

\section{Correlation between OS and surgical status}

As depicted in Figure 2, patients undergoing optimal debulking surgery had a 5-year OS better than those undergoing suboptimal debulkingsurgery, although this was not statistically significant. Nonetheless, we found a difference of 10 months of median survival between those two procedures, considered clinically meaningful. This result was in line with the study written by du Bois et al. [79], which discovered that optimal debulking yielded extremely more prolonged survival of 36.2 months than suboptimal debulking, which results in a survival time of 29.6 months. Optimal cytoreduction is a vital prognostic factor for lengthened survival, whether committed before or after chemotherapy [10] and with augmented OS [80].

\section{Correlation between $O S$ and $R D$}

We found that the 5-year OS and median survival in patients with RD was $9.1 \%$ and 2 months, compared to no RD was $45.9 \%$ and 39 months. In a study by Eisenkop et al. [81], the 5-year survival OS for present and no RD are $29 \%$ and $52 \%$, higher than our results. Similar results also were reflected from Scarabelli et al. [82] (42.2\% vs. 21.3\%). However, prior investigations have countered optimal surgery definitions depending on the residual tumor volume cut-off they used. In more detail, the median OS has been documented to be 34-64 months in women with no residual masses comparable to our results [83], [84], $\sim 38$ months for those with $<1 \mathrm{~cm}$ residual masses [85], [86], and 25-40 months for those with $<2 \mathrm{~cm}$ residual masses [87], [88].

\section{Correlation between OS and chemotherapy}

An analysis related to chemotherapy use demonstrated that half of the patients in this cohort did not receive adjuvant chemotherapy due to several factors: age-related circumstances (thus preferring palliative care), did not meet the criteria for adjuvant chemotherapy, already died before the chemotherapy cycle, did not consent to chemotherapy, and have financial, social, and location complexities which made them difficult to access healthcare in our institution. Clinical evidence sourced from guidelines on EOC therapy has ascertained that the first-choice combined chemotherapy of EOC is carboplatinpaclitaxel in neoadjuvant and adjuvant courses [89]. Our center also frequently combining a platinumderived compound (carboplatin, mainly, or cisplatin) and a taxane (paclitaxel) for therapeutic management of EOC. This agent combination appears to grant a more satisfactory response than the platinum-derived compound alone, augmenting EOC carriers' survival rate [89] and resulting in more prolonged median survival [Figure 3a]. In this cohort, regardless of the type and status of debulking surgery, the 5-year 
OS rate for advanced-stage EOC patients given adjuvant chemotherapy was $40 \%$ similar to a prior study $(39.2 \%)$ [90], with a median survival rate of 39 months. This value was not different statistically to those who did not get chemotherapy, whose OS was $34.8 \%$ and median survival was 29 months. Though not statistically significant, our findings align with Chang et al. [48], which suggests that taxane-based adjuvant chemotherapy improves 5-year survival. Our data implied that optimal PDS followed by platinumbased chemotherapy should be conducted to secure the prognosis of women with advanced-stage EOC. In a more detailed, patients who underwent suboptimal debulking surgery who were not followed by adjuvant chemotherapy had the poorest survival [Figure $3 \mathrm{~b}$ ].

\section{Correlation between OS and histopathology}

Analyzing the survival of our cases according to their histopathology subtypes demonstrated relatively higher 5-year OS results compared to a study by Zhou et al. [49] Their findings compared to our results was $28.1 \%$ versus $50 \%$ in serous EOC, $38.6 \%$ versus $25 \%$ in endometrioid EOC, $14.2 \%$ versus $33.3 \%$ in mucinous EOC, and $18.8 \%$ versus $21.4 \%$ in clear cell EOC, with a relatively longer median survival of 37 versus 39,40 versus 24,9 versus 45, and 19 versus 31 months, respectively [49]. We found that the mucinous and clear cell EOC have a poorer 5-year OS than the serous EOC, while endometrioid EOC had comparable results with the serous type. Seromucinous EOC had very high OS because there is only one subject; thus, it was unreliable and not statistically meaningful. In our analysis, the worst OS of clear-cell EOC was possibly attributed to clear-cell EOC being less chemosensitive than serous EOC [68]. Our study's insignificance of OS and median survival was aligned to a former study [91]. However, the median survival of serous EOC in our report was longer than results presented in the literature (18.2-29.3 months) [70], but shorter than results from a Turkish study (50.5 months) [69]. We found that the median survival of clear cell type among our patients was generally better than results found in the literature (6-14.2 months) [70].

We obtained no statistically significant difference in median survival when comparing the two major subtypes of serous and non-serous ovarian cancer. However, in our cohort, non-serous EOC tended to be linked with an increased risk of death among subjects with suboptimal residual tumor corresponding with serous EOC, reflecting low median survival (29 vs. 39 months). Patients with clear cell carcinoma and mucinous adenocarcinoma (both non-serous EOC) have a poorer response to platinum-based first-choice chemotherapy than serous EOC [91]. Although the pathology and prognosis of serous EOC are poor and often present with an advanced stage the response to adjuvant chemotherapy is quite good, which explains why the median survival was more protracted than found for non-serous EOC in our findings [89].

\section{Prognostic factors}

In Cox PHs model through bivariate and multivariate analysis, RD became a significant independent prognostic factor with an $\mathrm{HR}$ of 3.50 , higher than the value in the former study $(H R=1.76)$ [11] Consistent with several studies, we reported that $\mathrm{RD}$ at the end of cytoreductive surgery was the most substantial prognostic factor in advanced-stage EOC [75], [87], [92], [93], [94]. In those with non-serous EOC, residual tumor size was more linked with a rising risk of dying. Meanwhile, the first-line chemotherapy regimen administration was not a prognostic factor for advanced-stage EOC survival [91].

Clinicopathological and treatment profiles (age, debulking status, debulking type, and chemotherapy) might have prognostic significance. Nevertheless, we obtained no difference statistically in all those groups. In contrast, other studies confirmed that elderly age could be a poor survival factor and independent prognostic indicator for OS among patients with advanced-stage EOC [42], [95]. An age of over 64 years was one of the predictors of mortality in people with ovarian cancer [96]. As opposed to those findings, our patients were mostly ranging in the age of 50-60 years old, answering why median survival would not be significant statistically. Regarding histology, supporting our findings, a study stated that patients with non-serous EOC had a poorer prognosis, though this parameter was not statistically significant [91].

\section{Strengths and Limitations}

This study is important because it analyzes various clinical factors in patients with EOC. We added perspective on how treatment profile differs according to the stage, displayed serous EOC risk factors, and demonstrated suboptimal debulking surgery risk factors. Moreover, we conducted survival analyses according to various clinical circumstances. Furthermore, our study reaffirmed the prognostic significance of $R D$ status in the OS of advanced-stage EOC.

Nevertheless, several shortcomings that arise from this study should be noticed. First, this was a retrospective study in which potential reporting, selection, and recall biases are unavoidable and inherent to this method. Second, we recruited relatively small sample sizes due to difficulties approaching the eligible patients and the cancer registry system in Indonesia being less established. Third, we did not include patients with comorbidities whereas in the actual scenario, a significant number of ovarian cancer patients had comorbidities during their lifespan. 
Fourth, in our institution, surgery is generally the duty of a gynecological oncologist. Nevertheless, since our center is a teaching hospital, the procedure may be done by residents or fellows under the supervision of experienced experts, thus possibly influencing the rate of treatment and outcomes quality [70].

Despite those hurdles, this is the first comprehensive study about EOC from Indonesia contributing to the gynecologic oncology field worldwide from developing countries and Asian perspectives. We endeavored to tackle this drawback by conducting stratified analyses to adjust several variables and applying strict recruitment standards. We thus suppose that these research results are clinically pertinent.

\section{Conclusion}

We present a pioneering epidemiological report on advanced stage EOC from an Asian perspective, characterizing the Indonesian patients' clinicopathological, prognostic, and OS aspects. We have agreed with the literature that the carcinogenesis of the ovarian epithelium is related to aging, affecting a high proportion of menopausal women with the prominent characteristics: obese, married, with a normal age of menarche, multiparous, and never using contraception. EOC cases registered were mainly of serous type with FIGO stage IIIC. Patients with stage IV had a more significant proportion of suboptimal debulking and NAC-IDS, predominantly had RD, and were given adjuvant chemotherapy with mostly platinum-based regimens. Furthermore, we recorded that the risk of serous carcinoma was increased by menopausal status, and predictors of suboptimal debulking surgery were histopathology and FIGO staging. OS differed between the presence of RD. A significant prognostic factor for the 5-year OS of EOC was only RD. However, younger age, stage-III, optimal debulking, NAC-IDS, serous (compared to non-serous), mucinous (compared to specific subtypes) tend to have more prolonged median survival. Suboptimal debulking surgery not followed by adjuvant chemotherapy has the poorest survival. Meanwhile, optimal debulking without continuing adjuvant and suboptimal debulking accompanied by adjuvant become the therapies that lead to the most extended median survival.

Viewing the dearth of data relating to EOC epidemiology in Indonesia, we firmly consider that the information demonstrated herein has enlightened readers on the EOC characteristics in Asia and provided broader hints of the profile regarding this insidious disease entity. We strongly recommend developing sustainable and more effective public health policy to prevent ovarian cancer, such as conducting a massive campaign through online platforms and performing screening, including early diagnosis starting from primary care. Future research with a larger sample size and further external validation for the model predictors of serous subtype and suboptimal debulking surgery will benefit in understanding ovarian cancer.

\section{References}

1. Sung H, Ferlay J, Siegel RL, Laversanne M, Soerjomataram I, Jemal A, et al. Global cancer statistics 2020: GLOBOCAN estimates of incidence and mortality worldwide for 36 cancers in 185 countries. CA Cancer J Clin. 2021;71(3):209-49. https://doi. org/10.3322/caac. 21660

PMid:33538338

2. Momenimovahed Z, Tiznobaik A, Taheri S, Salehiniya H. Ovarian cancer in the world: Epidemiology and risk factors. Int $J$ Womens Health. 2019;11:287-99. https://doi.org/10.2147/IJWH. S197604

PMid:31118829

3. Farghaly SA. Advances in Diagnosis and Management of Ovarian Cancer. $1^{\text {st }}$ ed. New York, Boston, MA: Springer; 2014. p. 1-270.

4. Kang JH, Lai YL, Cheng WF, Kim HS, Kuo KT, Chen YL, et al. Clinical factors associated with prognosis in low-grade serous ovarian carcinoma: Experiences at two large academic institutions in Korea and Taiwan. Sci Rep. 2020;10(1):20012. https://doi.org/10.1038/s41598-020-77075-1

PMid:33203969

5. Coburn SB, Bray F, Sherman ME, Trabert B. International patterns and trends in ovarian cancer incidence, overall and by histologic subtype. Int J Cancer. 2017;140(11):2451-60. https:// doi.org/10.1002/ijc.30676

PMid:28257597

6. Torre LA, Trabert B, DeSantis CE, Miller KD, Samimi G, Runowicz CD, et al. Ovarian cancer statistics, 2018. CA Cancer J Clin. 2018;68(4):284-96. https://doi.org/10.3322/caac.21456 PMid:29809280

7. World Health Organization. International Agency for Research on Cancer. GLOBOCAN 2020: Indonesia. The Global Cancer Observatory. Geneva: World Health Organization; 2021. Available from: https://gco.iarc.fr/today/data/factsheets/ populations/360-indonesia-fact-sheets.pdf [Last accessed on 2021 Nov 20].

8. Wahidin M, Noviani R, Hermawan S, Andriani V, Ardian A Djarir $\mathrm{H}$. Population-based cancer registration in Indonesia. Asian Pac J Cancer Prev. 2012;13(4):1709-10. https://doi. org/10.7314/apjcp.2012.13.4.1709 PMid:22799393

9. Sfakianos GP, Havrilesky LJ. A review of cost-effectiveness studies in ovarian cancer. Cancer Control. 2011;18(1):59-64. https://doi.org/10.1177/107327481101800109

PMid:21273981

10. Gao Y, Li Y, Zhang C, Han J, Liang H, Zhang K, et al. Evaluating the benefits of neoadjuvant chemotherapy for advanced epithelial ovarian cancer: A retrospective study. J Ovarian Res. 2019;12(1):85. https://doi.org/10.1186/s13048-019-0562-9 PMid:31519183

11. Altman AD, Nelson G, Chu P, Nation J, Ghatage P. Optimal debulking targets in women with advanced stage ovarian cancer: A retrospective study of immediate versus interval debulking surgery. J Obstet Gynaecol Canada. 2012;34(6):558-66. 
https://doi.org/10.1016/S1701-2163(16)35272-0

PMid:22673172

12. Dahlan MS. Analisis Multivariat Regresi Logistik. $2^{\text {nd }}$ ed. Jakarta: Epidemiologi Indonesia; 2019. p. 1-175.

13. Dahlan MS. Analisis Survival: Dasar-Dasar Teori and Aplikasi Dengan Program SPSS. $1^{\text {st }}$ ed. Jakarta: Epidemiologi Indonesia; 2012. p. 1-90.

14. Laerd Statistics. Kaplan-Meier using SPSS Statistics. Lund Research Ltd.; 2018. Available from: https://statistics.laerd. com/spss-tutorials/kaplan-meier-using-spss-statistics.php [Last accessed on 2020 Nov 23].

15. Terplan M, Schluterman N, McNamara EJ, Tracy JK, Temkin SM Have racial disparities in ovarian cancer increased over time? An analysis of SEER data. Gynecol Oncol. 2012;125(1):19-24. https://doi.org/10.1016/j.ygyno.2011.11.025 PMid:22108636

16. Chornokur G, Amankwah EK, Schildkraut JM, Phelan CM. Global ovarian cancer health disparities. Gynecol Oncol. 2013;129(1):258-64. https://doi.org/10.1016/j. ygyno.2012.12.016 PMid:23266352

17. Suknikhom W, Muangtan S, Sananpanichkul P. Histopathological patterns of epithelial ovarian cancer at Prapokklao hospital: A five years retrospective study. 2018;35(3):257-267.

18. Lundberg FE, Iliadou AN, Rodriguez-Wallberg K, GemzellDanielsson K, JohanssonAL. The risk of breast and gynecological cancer in women with a diagnosis of infertility: A nationwide population-based study. Eur J Epidemiol. 2019;34(5):499-507. https://doi.org/10.1007/s10654-018-0474-9 PMid:30623293

19. Shen F, Chen S, Gao Y, Dai X, Chen Q. The prevalence of malignant and borderline ovarian cancer in pre-and postmenopausal Chinese women. Oncotarget. 2017;8(46):80589-94. https://doi.org/10.18632/oncotarget.20384

PMid:29113327

20. Kamajaya IG, Brahmantara BN, Wirawan AN. Profile of ovarian cancer patients in Mangusada Badung regional public hospital. Indones J Cancer. 2021;15(3):117.

21. Rodriguez C, Calle EE, Fakhrabadi-Shokoohi D, Jacobs EJ, Thun MJ. Body mass index, height, and the risk of ovarian cancer mortality in a prospective cohort of postmenopausal women. Cancer Epidemiol Biomarkers Prev. 2002;11(9):822-8. PMid: 12223425

22. Noela $\mathrm{F}$, Nuryanto $\mathrm{KH}$. Epidemiology data of ovarian cancer in Dr. Cipto Mangunkusumo Hospital, Jakarta. Indones J Obstet Gynecol. 2016;4(2):101.

23. Bandera CA. Advances in the understanding of risk factors for ovarian cancer. J Reprod Med. 2005;50(6):399-406. PMid:16050564

24. Batubara JRL, Soesanti F, van de Waal HD. Age at menarche in Indonesian girls: A national survey. Acta Med Indones. 2010;42(2):78-81.

PMid:20513931

25. Nnoaham KE, Webster $\mathrm{P}$, Kumbang J, Kennedy $\mathrm{SH}$, Zondervan KT. Is early age at menarche a risk factor for endometriosis? A systematic review and meta-analysis of casecontrol studies. Fertil Steril. 2012;98(3):702-12. https://doi. org/10.1016/j.fertnstert.2012.05.035

PMid:22728052

26. Lacroix AE, Gondal H, Langaker MD. Physiology, Menarche. Treasure Island, FL: StatPearls; 2021.

27. Fujita M, Tase T, Kakugawa Y, Hoshi S, Nishino Y, Nagase S, et al. Smoking, earlier menarche and low parity as independent risk factors for gynecologic cancers in Japanese: A case-control study. Tohoku J Exp Med. 2008;216(4):297-307. https://doi. org/10.1620/tjem.216.297

PMid:19060444

28. Jordan SJ, Webb PM, Green AC. Height, age at menarche, and risk of epithelial ovarian cancer. Cancer Epidemiol Biomarkers Prev. 2005;14(8):2045-8. https://doi.org/10.1158/1055-9965. EPI-05-0085

PMid:16103459

29. Titus-Ernstoff L, Perez K, Cramer DW, Harlow BL, Baron JA, Greenberg ER. Menstrual and reproductive factors in relation to ovarian cancer risk. Br J Cancer. 2001;84(5):714-21. https://doi. org/10.1054/bjoc.2000.1596

PMid: 11237375

30. Reid BM, Permuth JB, Sellers TA. Epidemiology of ovarian cancer: A review. Cancer Biol Med. 2017;14(1):9-32. https://doi. org/10.20892/j.issn.2095-3941.2016.0084 PMid:28443200

31. Gaitskell K, Green J, Pirie K, Barnes I, Hermon C, Reeves GK, et al. Histological subtypes of ovarian cancer associated with parity and breastfeeding in the prospective Million Women Study. Int J Cancer. 2018;142(2):281-9. https://doi.org/10.1002/ ijc.31063

PMid:28929490

32. Kobayashi $\mathrm{H}$. Potential scenarios leading to ovarian cancer arising from endometriosis. Redox Rep. 2016;21(3):119-26. https://doi.org/10.1179/1351000215Y.0000000038 PMid:26317761

33. Su D, Pasalich M, Lee AH, Binns CW. Ovarian cancer risk is reduced by prolonged lactation: A case-control study in Southern China. Am J Clin Nutr. 2013;97(2):354-9. https://doi. org/10.3945/ajcn.112.044719 PMid:23283498

34. Braem MG, Onland-Moret NC, van den Brandt PA, Goldbohm RA Peeters $\mathrm{PH}$, Kruitwagen RF, et al. Reproductive and hormonal factors in association with ovarian cancer in the Netherlands cohort study. Am J Epidemiol. 2010;172(10):1181-9. https://doi. org/10.1093/aje/kwq264

PMid:20861144

35. Budiana IN, Angelina M, Pemayun TG. Ovarian cancer: Pathogenesis and current recommendations for prophylactic surgery. J Turk Ger Gynecol Assoc. 2019;20(1):47-54. https://doi.org/10.4274/jtgga.galenos.2018.2018.0119 PMid:30362670

36. Fathalla MF. Incessant ovulation and ovarian cancer a hypothesis re-visited. Facts views Vis Obgyn. 2013;5(4):292-7. PMid:24753957

37. Tworoger SS, Fairfield KM, Colditz GA, Rosner BA, Hankinson SE. Association of oral contraceptive use, other contraceptive methods, and infertility with ovarian cancer risk. Am J Epidemiol. 2007;166(8):894-901.

PMid:17656616

38. Berchuck A, Schildkraut J. Oral contraceptive pills Prevention of ovarian cancer and other benefits. N C Med J. 1997;58(6):404-7; discussion 408.

PMid:9392951

39. Cramer DW, Titus-Ernstoff L, McKolanis JR, Welch WR, Vitonis AF, Berkowitz RS, et al. Conditions associated with antibodies against the tumor-associated antigen MUC1 and their relationship to risk for ovarian cancer. Cancer Epidemiol Biomarkers Prev. 2005;14(5):1125-31. https://doi. org/10.1158/1055-9965.EPI-05-0035 PMid:15894662

40. Jayson GC, Kohn EC, Kitchener HC, Ledermann JA. Ovarian cancer. Lancet (London, England). 2014;384(9951):1376-88. 
https://doi.org/10.1016/S0140-6736(13)62146-7 PMid:24767708

41. Collaborative Group on Epidemiological Studies of Ovarian Cancer, Beral V, Gaitskell K, Hermon C, Moser K, Reeves G, et al. Menopausal hormone use and ovarian cancer risk: Individual participant meta-analysis of 52 epidemiological studies. Lancet (London, England). 2015;385(9980):1835-42. https://doi.org/10.1016/S0140-6736(14)61687-1 PMid:25684585

42. Deng $\mathrm{F}, \mathrm{Xu} \mathrm{X}$, Lv M, Ren B, Wang $\mathrm{Y}$, Guo W, et al. Age is associated with prognosis in serous ovarian carcinoma. J Ovarian Res. 2017;10(1):36. https://doi.org/10.1186/ s13048-017-0331-6

PMid:28606125

43. Akgöl S, Aktürk E, Özaydın IY, Ölmez F, Karakaş S, Oğlak SC, et al. Serous epithelial ovarian cancer: Retrospective analysis of 260 cases. Aegean J Obstet Gynecol. 2021;3(1):19-21.

44. Vergote I, Tropé CG, Amant F, Kristensen GB, Ehlen T, Johnson $\mathrm{N}$, et al. Neoadjuvant chemotherapy or primary surgery in stage IIIC or IV ovarian cancer. N Engl J Med. 2010;363(10):943-53. https://doi.org/10.1056/NEJMoa0908806 PMid:20818904

45. Mizuno M, Kajiyama H, Shibata K, Mizuno K, Kawai M, Nagasaka T, et al. Prognostic value of histological type in stage IV ovarian carcinoma: A retrospective analysis of 223 patients. Br J Cancer. 2015;112(8):1376-83. https://doi.org/10.1038/ bjc. 2015.97

PMid:25867257

46. Lisio M-A, Fu L, Goyeneche A, Gao Z-H, Telleria C. Highgrade serous ovarian cancer: Basic sciences, clinical and therapeutic standpoints. Int J Mol Sci. 2019;20(4):952. https://doi.org/10.3390/ijms20040952 PMid:30813239

47. Weng CS, Wu CC, Chen TC, Chen JR, Huang CY, Chang CL. Retrospective analysis of comparative outcomes in recurrent platinum-sensitive ovarian cancer treated with pegylated liposomal doxorubicin (Lipo-dox) and carboplatin versus paclitaxel and carboplatin. Cancer Manag Res. 2019;11:9899-905. https://doi.org/10.2147/CMAR.S217329 PMid:31819627

48. Chang LC, Huang CF, Lai MS, Shen LJ, Wu FL, Cheng WF. Prognostic factors in epithelial ovarian cancer: A populationbased study. PLoS One. 2018;13(3):e0194993. https://doi. org/10.1371/journal.pone.0194993

\section{PMid:29579127}

49. Zhou J, Wu SG, Wang J, Sun JY, He ZY, Jin X, et al. The effect of histological subtypes on outcomes of stage IV epithelial ovarian cancer. Front Oncol. 2018;8:577. https://doi.org/10.3389/ fonc. 2018.00577

PMid:30564556

50. Gates MA, Rosner BA, Hecht JL, Tworoger SS. Risk factors for epithelial ovarian cancer by histologic subtype. Am J Epidemiol. 2010;171(1):45-53.

PMid:19910378

51. Gong TT, Wu QJ, Vogtmann E, Lin B, Wang YL. Age at menarche and risk of ovarian cancer: A meta-analysis of epidemiological studies. Int J Cancer. 2013;132(12):2894-900. https://doi. org/10.1002/ijc. 27952

PMid:23175139

52. Wentzensen N, Poole EM, Trabert B, White E, Arslan AA, Patel AV, et al. Ovarian cancer risk factors by histologic subtype: An analysis from the ovarian cancer cohort consortium. J Clin Oncol. 2016;34(24):2888-98.

PMid:27325851

53. Yang HP, Trabert B, Murphy MA, Sherman ME, Sampson JN,
Brinton LA, et al. Ovarian cancer risk factors by histologic subtypes in the NIH-AARP diet and health study. Int J Cancer. 2012;131(4):938-48. https://doi.org/10.1002/ijc.26469 PMid:21960414

54. Yang XR, Chang-Claude J, Goode EL, Couch FJ, Nevanlinna H, Milne RL, et al. Associations of breast cancer risk factors with tumor subtypes: A pooled analysis from the Breast Cancer Association Consortium studies. J Natl Cancer Inst. 2011;103(3):250-63. https://doi.org/10.1093/jnci/djq526 PMid:21191117

55. Arab M, Jamdar F, Hosseini MS, Ghodssi-Ghasemabadi R, Farzaneh F, Ashrafganjoei T. Model for prediction of optimal debulking of epithelial ovarian cancer. Asian Pac J Cancer Prev. 2018;19(5):1319-24. https://doi.org/10.22034/ APJCP.2018.19.5.1319 PMid:29802693

56. Feng LY, Liao S Bin, Li L. Preoperative serum levels of HE4 and CA125 predict primary optimal cytoreduction in advanced epithelial ovarian cancer: A preliminary model study. J Ovarian Res. 2020;13(1):17. https://doi.org/10.1186/s13048-020-0614-1 PMid:32050995

57. Llueca A, Climent MT, Escrig J, Carrasco P, Serra A, GomezQuiles $L$, et al. Validation of three predictive models for suboptimal cytoreductive surgery in advanced ovarian cancer. Sci Rep. 2021;11(1):1-8.

58. Gu Y, Qin M, Jin Y, Zuo J, Li N, Bian C, et al. A prediction model for optimal primary debulking surgery based on preoperative computed tomography scans and clinical factors in patients with advanced ovarian cancer: A multicenter retrospective cohort study. Front Oncol. 2021;10:611617.

59. Kang S, Nam BH. Does neoadjuvant chemotherapy increase optimal cytoreduction rate in advanced ovarian cancer? Metaanalysis of 21 studies. Ann Surg Oncol. 2009;16(8):2315-20. https://doi.org/10.1245/s10434-009-0558-6

PMid:19517192

60. Timmermans M, Sonke GS, Van de Vijver KK, van der Aa MA, Kruitwagen RF. No improvement in long-term survival for epithelial ovarian cancer patients: A population-based study between 1989 and 2014 in the Netherlands. Eur J Cancer. 2018;88:31-7. https://doi.org/10.1016/j.ejca.2017.10.030 PMid:29179135

61. Neesham D, Richards A, McGauran M. Advances in epithelial ovarian cancer. Aust J Gen Pract. 2020;49(10):665-9. https:// doi.org/10.31128/AJGP-09-19-5098 PMid:33015682

62. Kehoe S, Hook J, Nankivell M, Jayson GC, Kitchener H, Lopes $\mathrm{T}$, et al. Primary chemotherapy versus primary surgery for newly diagnosed advanced ovarian cancer (CHORUS): An open-label, randomised, controlled, non-inferiority trial. Lancet (London, England). 2015;386(9990):249-57. https://doi.org/10.1016/S0140-6736(14)62223-6 PMid:26002111

63. Wimberger $\mathrm{P}$, Lehmann $\mathrm{N}$, Kimmig $\mathrm{R}$, Burges $\mathrm{A}$, Meier $\mathrm{W}$, Hoppenau B, et al. Impact of age on outcome in patients with advanced ovarian cancer treated within a prospectively randomized phase III study of the Arbeitsgemeinschaft Gynaekologische Onkologie ovarian cancer study group (AGO-OVAR). Gynecol Oncol. 2006;100(2):300-7. https://doi. org/10.1016/j.ygyno.2005.08.029 PMid:16199079

64. Makar AP, Tropé CG, Tummers P, Denys H, Vandecasteele K. Advanced ovarian cancer: Primary or interval debulking? Five categories of patients in view of the results of randomized trials and tumor biology: Primary debulking surgery and interval debulking surgery for advanced ovarian cancer. Oncologist. 2016;21(6):745-54. https://doi.org/10.1634/ 
theoncologist.2015-0239

PMid:27009938

65. Fourcadier E, Trétarre B, Gras-Aygon C, Ecarnot F, Daurès JP, Bessaoud $F$. Under-treatment of elderly patients with ovarian cancer: A population based study. BMC Cancer. 2015;15:937.

66. Corvino R, De luliis F, D’Aniello D, Cefalì K, Ferraro E, LamazzaA, et al. Long-lasting stent placement in an elderly advanced ovarian cancer patient. Oncol Res Treat. 2016;39(3):146-8. https://doi.org/10.1159/000444273

PMid:27031123

67. Balducci L, Cohen HJ, Engstrom PF, Ettinger DS, Halter J, Gordon $\mathrm{LI}$, et al. Senior adult oncology clinical practice guidelines in oncology. J Natl Compr Canc Netw. 2005;3(4):572-90. https:// doi.org/10.6004/jnccn.2005.0032

PMid: 16038647

68. Pectasides D, Papaxoinis G, Fountzilas G, Aravantinos G, Bamias A, Pavlidis N, et al. Epithelial ovarian cancer in Greece: A retrospective study of 1,791 patients by the Hellenic cooperative oncology group (HeCOG). Anticancer Res. 2009;29(2):745-51. PMid:19331231

69. Kotsopoulos J, Moody JR, Fan I, Rosen B, Risch HA, McLaughlin JR, et al. Height, weight, BMI and ovarian cancer survival. Gynecol Oncol. 2012;127(1):83-7. https://doi. org/10.1016/j.ygyno.2012.05.038 PMid:22713293

70. Makar AP, Baekelandt M, Tropé CG, Kristensen GB. The prognostic significance of residual disease, FIGO substage, tumor histology, and grade in patients with FIGO stage III ovarian cancer. Gynecol Oncol. 1995;56(2):175-80. https://doi. org/10.1006/gyno.1995.1027

PMid:7896181

71. Matulonis UA, Sood AK, Fallowfield L, Howitt BE, Sehouli J, Karlan BY. Ovarian cancer. Nat Rev Dis Prim. 2016;2:16061. PMid:27558151

72. Stashwick C, Post MD, Arruda JS, Spillman MA, Behbakht K, Davidson SA, et al. Surgical risk score predicts suboptimal debulking or a major perioperative complication in patients with advanced epithelial ovarian, fallopian tube, or primary peritoneal cancer. Int J Gynecol Cancer. 2011;21(8):1422-7. https://doi. org/10.1097/IGC.0b013e31822c7704

PMid:21997170

73. Bilici A, Salepci T, Dane F, Gumus M, Ustaalioglu BBO, Seker M, et al. Neoadjuvant chemotherapy followed by interval cytoreductive surgery in patients with unresectable, advanced stage epithelial ovarian cancer: A single centre experience. Arch Gynecol Obstet. 2010;282(4):417-25. https://doi.org/10.1007/ s00404-009-1330-7

PMid:20035339

74. van der Burg $M E$, van Lent $M$, Buyse $M$, Kobierska $A$, Colombo N, Favalli G, et al. The effect of debulking surgery after induction chemotherapy on the prognosis in advanced epithelial ovarian cancer. Gynecological cancer cooperative group of the European organization for research and treatment of cancer. N Engl J Med. 1995;332(10):629-34. https://doi.org/10.1056/ NEJM199503093321002

PMid:7845426

75. Morice P, Brehier-Ollive D, Rey A, Atallah D, Lhommé C, Pautier $\mathrm{P}$, et al. Results of interval debulking surgery in advanced stage ovarian cancer: An exposed-non-exposed study. Ann Oncol. 2003;14(1):74-7. https://doi.org/10.1093/ annonc/mdg003 PMid:12488296

76. Leary A, Cowan R, Chi D, Kehoe S, Nankivell M. Primary surgery or neoadjuvant chemotherapy in advanced ovarian cancer: The debate continues. Am Soc Clin Oncol Educ B. 2016;35:153-62.
https://doi.org/10.1200/EDBK_160624

PMid:27249696

77. Rauh-Hain JA, Rodriguez N, Growdon WB, Goodman AK, Boruta DM, Horowitz NS, et al. Primary debulking surgery versus neoadjuvant chemotherapy in stage IV ovarian cancer. Ann Surg Oncol. 2012;19(3):959-65. https://doi.org/10.1245/ s10434-011-2100-x PMid:21994038

78. Traina TA, Dugan U, Higgins B, Kolinsky K, Theodoulou M, Hudis CA, et al. Optimizing chemotherapy dose and schedule by Norton-Simon mathematical modeling. Breast Dis. 2010;31(1):7-18. https://doi.org/10.3233/BD-2009-0290 PMid:20519801

79. Du Bois A, Reuss A, Pujade-Lauraine E, Harter P, Ray-Coquard I, Pfisterer J. Role of surgical outcome as prognostic factor in advanced epithelial ovarian cancer: A combined exploratory analysis of 3 prospectively randomized phase 3 multicenter trials: By the arbeitsgemeinschaft gynaekologische onkologie studiengruppe ovarialkarzin. Cancer. 2009;115(6):1234-44. https://doi.org/10.1002/cncr.24149

PMid:19189349

80. Chi DS, Eisenhauer EL, Zivanovic O, Sonoda Y, Abu-Rustum NR, Levine DA, et al. Improved progression-free and overall survival in advanced ovarian cancer as a result of a change in surgical paradigm. Gynecol Oncol. 2009;114(1):26-31. https://doi. org/10.1016/j.ygyno.2009.03.018

PMid: 19395008

81. Eisenkop SM, Friedman RL, Wang HJ. Complete cytoreductive surgery is feasible and maximizes survival in patients with advanced epithelial ovarian cancer: A prospective study. Gynecol Oncol. 1998;69(2):103-8. https://doi.org/10.1006/ gyno.1998.4955

PMid:9600815

82. Scarabelli C, Gallo A, Franceschi S, Campagnutta E, De G, Giorda G, et al. Primary cytoreductive surgery with rectosigmoid colon resection for patients with advanced epithelial ovarian carcinoma. Cancer. 2000;88(2):389-97. https://doi.org/10.1002/ (sici)1097-0142(20000115)88:2<389:aid-cncr21>3.0.co;2-w PMid: 10640973

83. Tropé CG, Elstrand MB, Sandstad B, Davidson B, Oksefjell H. Neoadjuvant chemotherapy, interval debulking surgery or primary surgery in ovarian carcinoma FIGO stage IV? Eur J Cancer. 2012;48(14):2146-54. https://doi.org/10.1016/j. ejca.2012.01.031

PMid:22382201

84. Wimberger $P$, Wehling M, Lehmann N, Kimmig R, Schmalfeldt $B$, Burges $A$, et al. Influence of residual tumor on outcome in ovarian cancer patients with FIGO stage IV disease: An exploratory analysis of the AGO-OVAR (Arbeitsgemeinschaft Gynaekologische Onkologie Ovarian Cancer Study Group). Ann Surg Oncol. 2010;17(6):1642-8. https://doi.org/10.1245/ s10434-010-0964-9

PMid:20165986

85. Bristow RE, Montz FJ, Lagasse LD, Leuchter RS, Karlan BY. Survival impact of surgical cytoreduction in stage IV epithelial ovarian cancer. Gynecol Oncol. 1999;72(3):27887. https://doi. org/10.1006/gyno.1998.5145 PMid: 10053096

86. Elstrand MB, Sandstad B, Oksefjell H, Davidson B, Tropé CG Prognostic significance of residual tumor in patients with epithelial ovarian carcinoma stage IV in a 20 year perspective. Acta Obstet Gynecol Scand. 2012;91(3):308-17.

87. Akahira JI, Yoshikawa H, Shimizu Y, Tsunematsu R, Hirakawa T, Kuramoto $\mathrm{H}$, et al. Prognostic factors of stage IV epithelial ovarian cancer: A multicenter retrospective study. 
Gynecol Oncol. 2001;81(3):398-403. https://doi.org/10.1006/ gyno.2001.6172

PMid:11371128

88. Munkarah AR, Hallum AV $3^{\text {rd }}$, Morris M, Burke TW, Levenback C, Atkinson EN, et al. Prognostic significance of residual disease in patients with stage IV epithelial ovarian cancer. Gynecol Oncol. 1997;64(1):13-7.

PMid:8995541

89. Colombo N, Sessa C, Du Bois A, Ledermann J, McCluggage WG, McNeish I, et al. ESMO-ESGO consensus conference recommendations on ovarian cancer: Pathology and molecular biology, early and advanced stages, borderline tumours and recurrent disease. Int J Gynecol Cancer. 2019;29(4):728-60. https://doi.org/10.1093/annonc/mdz062 PMid:31046081

90. Fu Y, Wang X, Pan Z, Xie X. Clinical outcomes and prognostic factors of patients with epithelial ovarian cancer subjected to first-line treatment: A retrospective study of 251 cases. Front Med China. 2014;8(1):91-5. https://doi.org/10.1007/ s11684-014-0305-7

PMid:24370920

91. Hosono S, Kajiyama H, Mizuno K, Sakakibara K, Matsuzawa K Takeda A, et al. Comparison between serous and nonserous ovarian cancer as a prognostic factor in advanced epithelial ovarian carcinoma after primary debulking surgery. Int J Clin Oncol. 2011;16(5):524-32. https://doi.org/10.1007/ s10147-011-0223-5

PMid:21431342
92. Winter WE $3^{\text {rd }}$, Maxwell GL, Tian C, Sundborg MJ, Rose GS, Rose PG, et al. Tumor residual after surgical cytoreduction in prediction of clinical outcome in stage IV epithelial ovarian cancer: A gynecologic oncology group study. J Clin Oncol. 2008;26(1):83-9. https://doi.org/10.1200/JCO.2007.13.1953 PMid: 18025437

93. Chi DS, Liao JB, Leon LF, Venkatraman ES, Hensley ML, Bhaskaran D, et al. Identification of prognostic factors in advanced epithelial ovarian carcinoma. Gynecol Oncol. 2001;82(3):532-7. https://doi.org/10.1006/gyno.2001.6328 PMid:11520151

94. Winter WE $3^{\text {rd }}$, Maxwell GL, Tian C, Carlson JW, Ozols RF, Rose PG, et al. Prognostic factors for stage III epithelial ovarian cancer: A gynecologic oncology group study. J Clin Oncol. 2007;25(24):3621-7. https://doi.org/10.1200/JCO.2006.10.2517 PMid:17704411

95. Bun S, Yunokawa M, Ebata T, Shimomura A, Shimoi T, Kodaira M, et al. Feasibility of dose-dense paclitaxel/carboplatin therapy in elderly patients with ovarian, fallopian tube, or peritoneal cancer. Cancer Chemother Pharmacol. 2016;78(4):745-52. https://doi. org/10.1007/s00280-016-3100-0

PMid:27522647

96. Ørskov $M$, lachina $M$, Guldberg $R$, Mogensen $O$, Nørgård BM. Predictors of mortality within 1 year after primary ovarian cancer surgery: A nationwide cohort study. BMJ Open. 2016;6(4):e010123. https://doi.org/10.1136/ bmjopen-2015-010123

PMid:27103625

Author Queries???

AQ1: Kindly provide author ORCID

AQ2: Kindly provide history details

AQ3: Kindly provide page number

AQ4: Kindly provide department 